\title{
Network additionality and policy mix of regional and national public support for innovation
}

David Douglas, Leeds Beckett University

Dragana Radicic, University of Lincoln

\begin{abstract}
Applying a multilevel treatment model to a sample of Spanish manufacturing firms, we evaluate the joint impact of regional and national funding on firms' cooperative relationships. A joint provision of public support from different administrative levels is termed a multilevel innovation policy mix. Because of heterogeneity in innovation behaviour and performance, we separately analyse small and medium-sized enterprises (SMEs) and large firms. Our empirical findings show heterogenous results with respect to both firm size and a type of cooperative partners. For SMEs, a multilevel policy mix has a synergistic effect on cooperation with customers. For other cooperative partners, the joint effectiveness depends on the comparison group. Namely, both sources jointly are more effective than regional support in isolation in promoting cooperation with suppliers and universities. For those SMEs that are funded from central government, a multilevel governance is effective in case of cooperation with government agencies and consultants. With regards to large firms, we find a limited evidence on complementarity between regional and national support. Namely, the policy mix is effective when large firms cooperate with other firms, specifically with customers and competitors. In contrast, empirical findings suggest no complementary effects for cooperation with knowledge providers.
\end{abstract}

Keywords: Policy mix; Network additionality; Multilevel governance; Behavioural additionality; Multilevel treatment model

\section{Introduction}

This study investigates the policy mix effects of regional and national R\&D subsides on the cooperative behaviour of Spanish manufacturing firms. The study combines two streams of research: the one exploring different types of additionality effects (input, output and behavioural; our focus is on behavioural additionality, in particular network additionality); and the other concerning the innovation policy mix, in particular a multilevel governance. 
With respect to types of additionality effects, until recently, evaluation of innovation policies has mainly been concerned with input and output additionalities, whereby input additionality occurs when firms increase their $R \& D$ investment as a result of receiving subsidies; and output additionality results in new patents, product and process innovations or increased innovative sales (a share of turnover from new products). Focusing on innovation inputs and outputs, however, means that we stay outside the 'black box' of innovation processes, rather observing the beginning (innovation inputs) or end results (innovation outputs) of processes (Hall and Maffioli 2008; Marzucchi and Montresor 2015; OECD 2006; Teirlinck and Spithoven 2012).

The concept of behavioural additionality invites us to go beyond input and output additionality and assess the impact of public support on firms' innovative behaviour. The literature on additionality lacks a common definition of behavioural additionality. Most empirical studies explore network or cooperation additionality (Georghiou and Clarysse 2006), which occurs when firms expand their networks and cooperative activities as a result of participation in support programmes. Given that data on other types of behavioural additionality are not available to us, we follow this tradition by exploring network additionality.

Concerning the second stream of research, the concept of policy mix is increasingly gaining grounds amongst researchers and policy makers. Namely, the justification for public intervention in the domain of innovation stems from two interrelated types of approaches: market and systemic failures. Consequently, one of the main features of R\&D and innovation policy is the existence of a large number of policy instruments designed to mitigate these failures (Cunningham et al. 2016b; Flanagan and Uyarra 2016). Furthermore, the complexity of innovation policy is characterized by two dimensions: the instrument mix (Rogge and Reichardt, 2016); and a multilevel governance (Flanagan, Uyarra, and Laranja 2011; Magro, Navarro, and Zabala-Iturriagagoitia 2014). ${ }^{1}$ The former encompasses a combination of interacting policy instruments from different domains, while the latter is concerned with policy rationales, domains and instruments implemented at different administrative (regional, national and supranational) levels (Lanahan and Feldman 2015; Magro and Wilson 2013; 2019).

It is important to take into account the policy mix in evaluating innovation policies, as they show the extent to which policy goals are achieved (Flanagan, Uyarra, and Laranja 2011).

\footnotetext{
1 The interaction of public support at different government levels is termed a multilevel governance (Flanagan Uyarra, and Laranja 2011; Martin 2016), policy-mix 'verticality' (Howlett, How, and del Rio 2015); and a multilevel innovation policy mix (Magro and Wilson 2013; Lanahan and Feldman 2015).
} 
Moreover, if evaluators do not control for the existence of multiple sources of public support, the policy effects of a single public instrument might be overestimated (Guerzoni and Raiteri 2015). As the need to account for the innovation policy mix has only been recently emphasized in the literature (Guerzoni and Raiteri 2015), empirical studies on the topic are scarce (Uyarra and Flanagan 2010), and most of them focus on the instrument mix (Cunningham et al. 2016b; Rogge and Reichardt 2016), while very few studies examine the interactions in the governance space (Fernández-Ribas 2009). The main contribution of this study is the analysis of a multilevel innovation policy mix by investigating the joint effectiveness of regional and national innovation policies. Moreover, this is among first studies to provide empirical findings in relation to network additionality in the context of a multilevel governance. National innovation policy does not take into account regional heterogeneity, and as such should be complemented by regional policy which is context-specific, thereby accounting for regional specificities and local path dependence (Marzucchi and Montresor 2015). Therefore, from the theoretical perspective, we would expect a complementary relationship between policies implemented at different governance levels. However, this synergistic effect would primarily arise if national and regional policies are coordinated, so the duplication of efforts is avoided (Marzucchi and Montresor 2015). ${ }^{2}$ If the policies are not coordinated (known as a policy coordination failure) (Schot and Steinmueller 2018), their joint effectiveness could be either the same as their policy effects in isolation or even smaller. Consequently, the effectiveness of the multilevel policy mix is an empirical, rather than theoretical issue, which means that our study is of exploratory nature. ${ }^{3}$ More specifically, we do not formulate hypotheses, but aim to answer the following research question: Are the joint effects of national and regional public support larger than their individual effects?

The second contribution of the study is examining a multilevel governance separately in SMEs and large firms. Usually, national innovation policy provides support for large-scale projects, while regional policy is more concerned with promoting innovation activities in small firms (Afcha-Chàvez 2011; Afcha-Chàvez and García-Quevedo 2016; Marzucchi and Montresor 2015). Accordingly, we report separate estimates of the joint effects of regional and national subsidies for both small and medium-sized enterprises (SMEs) and for large firms. We

\footnotetext{
${ }^{2}$ Avoiding duplication and fragmentations of efforts is the integral element of the smart specialisation strategy as well.

${ }^{3}$ The same point is noted in the evaluation studies on individual policy instruments. For instance, Dimos and Pugh (2016, p. 797) argue with respect to the effectiveness of R\&D subsidies on innovation inputs and outputs: "There is neither theoretically nor empirically definitive guidance on the effectiveness of public R\&D subsidies in stimulating private R\&D."
} 
expect that the effects of public support on innovation and, hence, innovation-related activities including cooperation, will be influenced by the resource advantages of large firms - both human and financial - and by SME advantages with respect to flexibility and reaction speeds. But again, concerning the multilevel policy mix, we cannot a priori postulate what type of effects will be found in firms of different sizes.

The paper is organised as follows. Section 2 discusses innovation policy in the Spanish context, while Section 3 defines the concept of behavioural additionality and its various categories, discusses the motives for cooperation with various partners, defines the concept of policy mix and reviews empirical evidence. Section 4 formulates the methodological framework, discusses the model specification and data used in the study. Section 5 presents empirical results, which are discussed in Section 6. Finally, Section 7 concludes.

\section{Context of analysis}

According to the Innovation Union Scoreboard (2013), Spain is among the countries characterized as "moderate" innovators (i.e. below the innovation "leaders" and "followers", but above the "modest" innovators). Spain provides a particularly suitable context for studying a multilevel innovation policy mix. Strong decentralization to Spain's 17 Autonomous Regions (NUTS2, Comunidades Autónomas) dictates that these exist alongside each other. Some policies are more conducive to supporting innovation at the national level, in particular, innovation activities that require larger financial support, while others are more conducive to fostering innovation at a sub-national (regional and sub-regional) levels, such as networking policies (Margo and Wilson 2013). However, in practice, both types of policies are implemented at all administrative levels. For instance, Spanish innovation policy is particularly focused on direct business $R \& D$ and business innovation and $R \& D$ subsidies, as the most important policy instrument, are provided at both regional and national level (OECD 2011, p. 307). The two sources of public funding differ in the magnitude of support provided, which is larger in case of national support, as well as in the scope of their design.

In relation to policy instruments aimed at fostering cooperation, the situation is Spain is quite complex (for a review of policy instruments, see Table 1 below). For instance, cluster policy instruments, which are often sectoral and mainly firm-based, are only implemented at the regional level (OECD 2011; p. 307). However, the other three instruments designed to promote cooperation (technology platforms, science and technology parks, and incubators for new firms, see Table 1) are implemented at both regional and national levels. Therefore, it is 
not possible to disentangle the domain of national from regional support, as there is a significant overlap between them. Given that the survey question we utilise to create the treatment variable (see the Methodology section below) does not specify types of policy instruments that are implemented at regional and national levels, we are unable to infer the expected effectiveness of public support provided at each administrative level.

Table 1. Policy instruments at national and regional levels in Spain

\begin{tabular}{|l|c|c|}
\hline \multicolumn{1}{|c|}{ Instruments by level of government } & $\begin{array}{c}\text { National } \\
\text { support }\end{array}$ & $\begin{array}{c}\text { Regional } \\
\text { support }\end{array}$ \\
\hline$R \& D$ investment & Yes & Yes \\
\hline $\begin{array}{l}|l| \\
\text { On-going institutional R\&D funding in public }\end{array}$ & No & Yes \\
\hline Seed funding to start PRCs or HEIs & Yes & Yes \\
\hline Competitive R\&D funding by PRCs or HEIs & Yes & Yes \\
\hline Public subsidies for private R\&D & Yes & No \\
\hline Tax credits for private R\&D & No & Yes \\
\hline Innovation collaboration & No & Yes \\
\hline Cluster initiatives & Yes & Yes \\
\hline Branded excellence poles or hubs & Yes & Yes \\
\hline Multi-disciplinary technology platforms & Yes & Yes \\
\hline Science and technology parks & & \\
\hline Incubators for new firms &
\end{tabular}

Source: OECD (2011 p. 307).

In addition, regional policy in Spain tends to focus more on innovative SMEs than national policy (Afcha-Chàvez 2011; Afcha-Chàvez and García-Quevedo 2016; Marzucchi and Montresor 2015). Regional innovation policy in Spain encourages SMEs to apply for funding by setting the minimum budget requirements much lower than they are set for national programmes (Faiña and Lopez-Rodriguez 2010). For SMEs, the importance of non-legal protection of intellectual property suggests that, compared to vertical cooperation (customers and suppliers), public support may be less able to induce horizontal cooperation (competitors) and more able to induce cooperation with public sector bodies (HEIs). As regional policy is particularly concerned with promoting types of additionality other than input additionality and 
has a particular focus on innovative SMEs, it is possible that regional policy may be more effective than national policy in promoting SME cooperative behaviour.

\section{Literature review}

\subsection{Concept of behavioural additionality}

Until recently, scholars assessing the effectiveness of R\&D and innovation public support have focused their attention on input and output additionality, that is, whether public support induces larger innovation inputs and outputs as results of public intervention. Both concepts are closely associated with the linear model of innovation and the market-failure rationale for public interventions (Antonioli and Marzucchi 2012; Hall and Maffioli 2008; Marzucchi and Montresor 2015; Wanzenböck, Scherngell, and Fischer 2013). However, the limitations of the linear model of innovation and the prominence of later generations of innovation models (from the Kline-Rosenberg chain-linked model to the fifth generation of networking models) coupled with new developments within evolutionary economics (Nelson and Winter 1982) and the related innovation system perspective (Edquist 1999), in particular regarding the system-failure rationale for public support, have led to the emergence of the concept of behavioural additionality (Antonioli and Marzucchi 2012; Gök and Edler 2012; Teirlinck and Spithoven 2012; Wanzenböck, Scherngell, and Fischer 2013).

Theoretical reasoning behind evolutionary economics and later generations of innovation models consider the innovation process as non-linear and a complex process, not restricted to the boundaries of the firm, but expanding to include the entire innovation system with its institutions and organizations (Antonioli and Marzucchi 2012; Marzucchi and Montresor 2015). Behavioural additionality was first introduced by Buisseret, Cameron, and Georghiou (1995) and defined as changes in firms' innovation behaviour arising from public support (Magro and Wilson 2013). It is a broader concept than input and output additionality, which is one of the reasons why it lacks a clear-cut definition (Antonioli and Marzucchi 2012; Gök and Edler 2012; Cerulli Gabriele, and Potì 2016) and a commonly accepted classification (Falk 2007). Although the literature advances a broad perspective on behavioural additionality, most empirical studies investigate only one segment (Antonioli and Marzucchi 2012); that is the impact of public intervention on firms' cooperative behaviour (scope additionality as defined by Falk 2007; or network or cooperation additionality following the OECD 2006, definition). 


\subsection{Cooperation for innovation with different partners}

Theoretical arguments about the reasons why firms cooperate with other economic agents are discussed in the Industrial Organization and the Management literature (Franco and Gussoni 2014). The first approach focuses on incoming and outcoming spillovers from technological knowledge. When incoming spillovers (i.e. knowledge absorbed from the outside of a firm's boundaries) are high, firms are more likely to benefit from cooperation. However, these benefits can be reduced if a cooperative partner engages in opportunistic behaviour or if the imperfect appropriability of technological knowledge results in knowledge leakage. When a cooperative relationship does not clearly specify which partner will be assigned exclusive property rights, then cooperation might be sub-optimal or even terminated (Dhont-Peltrault and Pfister 2011). The risk of cooperation failure is of high importance when a firm decides whether to cooperate with a particular partner. ${ }^{4}$ In particular, SMEs might face a higher risk of cooperation failure in cooperating with competitors (Radicic and Pugh 2017). Competing firms could try to capture the other firm's knowledge (i.e. to maximize incoming spillovers) while, at the same time, trying to minimize the transfer of their own knowledge to the other firm (to minimize outgoing spillovers) (Belderbos, Carree, and Lokshin 2004).

The second, Management approach, offers two partly complementary views on firms' cooperative behaviour. The first view is advanced in the transaction costs economics, in which a firm's decision to "make" or "buy" depends on which decision will minimise transaction costs (Williamson 1985). In case of high transaction costs, a firm will opt to internalise a transaction (in our context, innovation activity), while a market transaction is optimal it entails low transaction costs. Concerning the third, hybrid option, in which firms will cooperate with other economic agents, the main motive for cooperation is gaining access to similar resources, whereby internal and external knowledge are treated as substitutes (Franco and Gussoni 2014). The benefits of accessing similar resources are associated with benefiting from economics of scale and scope (Teirlinck and Spithoven 2012), and sharing risk and uncertainty (Cantabene and Grassi 2019). Given that competing firms usually have similar resources, this theoretical

\footnotetext{
${ }^{4}$ Cooperation failure at a firm level should be distinguished from a policy coordination failure.
} 
argument is particularly appropriate in case of cooperation with competitors (Miotti and Sachwald 2003).

The second management framework explaining firms' cooperation is the resourcebased view. Firms engage in cooperative behaviour to utilise and expand their internal knowledge base, i.e. absorptive capacity. Namely, by accessing both complementary and similar knowledge from other firms and organisations, firms can expend their absorptive capacity and, in that way, obtain a competitive advantage over other firms (Arranz and Arroyabe 2008; Franco and Gussoni 2014). This argument is consistent with another important framework in the innovation literature, that of innovation ecosystem, in which cooperation for innovation, besides integrated value chains, is its core attribute. Within a wider innovation ecosystem, technological diversity among firms and other economic agents is the basic motivation for cooperation for innovation. Greater technological diversity increases the probability of firms' collaborating on complex products that are harder to imitate, and as such, become a source of firms' competitive advantage (Radicic, Pugh, and Douglas 2020).

\subsection{Innovation policy mix}

In the last few decades, the evolution of contemporary policies for fostering and stimulating innovation has resulted in an increasingly complex mix of policies and programmes. The main reason for this increased complexity is the co-existence of two policy rationales; alongside the neoclassical market-failure rationale, an evolutionary-systemic rationale has emerged as a complementary basis for justifying public intervention in the domain of innovation. Whilst the market-failure rationale emphasizes the importance of investing in science and technology, the evolutionary-systemic rationale focuses on the interaction of organizations and institutions within systems of innovation. A direct consequence of the widening of policy rationales is the introduction and implementation of a large number of policy instruments (Borrás 2009; Ghazinoory et al. 2019). Accordingly, the innovation policy domain is characterized by the existence of complementary policy rationales, accompanied by a complementary mix of policy instruments. To reflect the widening of policy rationales and a proliferation of various policy instruments, the concept of the instrument policy mix has only recently emerged (Flanagan, Uyarra, and Laranja 2011).

Besides the instrument policy mix, there is another dimension of the innovation policy mix termed a multilevel innovation policy mix (Magro and Wilson 2013) or vertical interaction (Ghazinoory et al. 2019). In other words, the complexity of innovation policies is further 
actuated by the broadening of policy domains (Borrás 2009; Ghazinoory et al. 2019), such that the implementation of innovation policies is conducted at different administrative levels - local, regional, national, and supra-national. The implications are that a wide range of policy measures implemented at all administrative levels are interacting with one another (Flanagan, Uyarra, and Laranja 2011; Martin 2016).

Policies at different administrative level, regardless of their differences, share a common directive - bolstering economic activity. While national innovation policies are aimed at increasing a country's international competitiveness, regional innovation policies are designed to spur innovation within a specific region. National innovation policies usually have greater resources at their disposal than regional ones (Lanahan and Feldman 2015).

Theoretically, the interaction in the policy mix could result in: a) complementary or synergistic effects; b) trade-offs, such that one instrument reduces the effectiveness of the other(s); and c) no interactions between instruments (Cunningham et al. 2016b; Magro and Wilson 2013; Martin 2016; OECD 2010). With respect to synergistic effects, the literature on innovation policy mix distinguishes between two types of complementarity: operational complementarity, which arises when policy interventions result in synergistic effects during their diffusion but are not designed as complementary; and strategic complementarity, which is associated with policy interventions designed to achieve synergistic effects. The few studies that explore the effectiveness of public support in the policy mix context focus on operational complementarity (Cunningham et al. 2016b; SQW Consulting 2009). Our study is no exception in this respect, reflecting the lack of strategic policies and corresponding data.

In contrast to complementarity, suboptimal outcomes of policy mixes are very common in cases of policy layering, i.e. adding new policy tools and objectives to old ones (Howlett, How, and del Rio 2015). If the objective of policy makers is to achieve an optimal policy mix, rather than the optimal outcome of individual instruments and objectives, then policy mechanisms must be implemented comprehensively, not individually (del Río 2014). Moreover, policy coordination is needed so duplication and overlap of efforts can be either minimized or completely avoided. However, the lack of coordination is quite common between isolated government departments that design and implement related policies (Magro, Navarro, and Zabala-Iturriagagoitia 2014). Therefore, all three outcomes of the policy mix (complementarity, substitution or no interaction) could be potentially reported when conducting a quantitative evaluation. 


\subsection{Empirical evidence on innovation policy mix}

Relative to input and output additionality, behavioural additionality is the subject of a small number of studies (Antonioli and Marzucchi 2012; Marzucchi, Antonioli, and Montresor 2015; Cerulli, Gabriele, and Potì 2016; Cunningham, Gök, and Laredo 2016a); ${ }^{5}$ and most of these report findings on network or cooperation additionality (for a review of studies see e.g. Cunningham and Gök 2012; Radicic, Pugh, and Douglas 2020). Overall, the empirical evidence almost uniformly indicates positive behavioural additionality. This conclusion echoes Cunningham, Gök, and Laredo (2016a), who note that although a negative behavioural additionality (or crowding out) is theoretically viable, empirical evidence are conclusive in reporting positive additionality.

Concerning previous empirical studies on the policy mix, they mainly focus on three domains. The first and the most investigated aspect is between direct measures ( $R \& D$ subsidies) and indirect measures (tax incentives). Overall, studies report complementarity between these measures (for the review see Cunningham et al., 2016b). Concerning behavioural additionality in the context of SMEs, Radas et al. (2015) explore the individual and joint effects of direct subsidies and tax incentives on R\&D collaboration of Croatian SMEs with research institutions. The results suggest no complementary relationship, i.e. while subsidies alone increase the probability of collaboration, the joint impact of both subsidies and tax incentives is not significant. The second stream of research on the innovation policy mix focuses on the interaction between the supply-side and the demand-side policy measures, in particular public procurement. Empirical evidence (see Aschhoff and Sofka 2009; Guerzoni and Raiteri 2015; Radicic 2019), although scarce, indicates that innovative procurement is effective in promoting firms' innovation performance.

The third stream of research explores a multilevel policy mix. As there are no empirical studies reporting the joint effects of public support from different administrative levels, we review the studies that distinguish between national and regional support in the context of behavioural additionality. ${ }^{6}$ Fernández-Ribas (2009) evaluates the effectiveness of regional,

\footnotetext{
${ }^{5}$ Behavioural additionality is a complementary concept to input and output additionality (Antonioli and Marzucchi 2012; Cerulli, Gabriele, and Potì 2016; Cunningham, Gök, and Laredo 2016a; Radicic, Pugh, and Douglas 2020). This gives rise to the possibility of finding that public support results in behavioural additionality, but at the same time not inducing input and output additionality (Gök and Edler 2012).

${ }^{6}$ Czarnitzki and Lopes-Bento (2014) estimate the individual and joint effectiveness of European and national funding on innovation input and output in German firms. Although this study reports the joint effects of funding from different administrative levels, it focuses on input and output additionality.
} 
national and EU support employing the Spanish CIS data during 2002-2004. Although the study reports individual treatment effects of national and regional support on cooperation with universities, customers, suppliers and competitors, it does not report their joint effects. Interestingly, the estimated treatment effects for cooperation with domestic partners are quantitatively the same for both levels of support. Afcha Chàvez (2011), using the Spanish survey of business strategy for the period 1995-2005, reports no innovation policy effects on vertical cooperation (with customers and suppliers) from either national or regional support, but finds significant effects of both types of support on cooperation with universities (although only marginally significant at the $10 \%$ level for regional support). Therefore, it seems that the only strong behavioural additionality is found for national support and its impact on cooperation with universities. Finally, Marzucchi and Montresor (2015) analyse the effectiveness of national and regional support in Italy and Spain using the fourth wave of the CIS data, covering the period 2002-2004. The authors explore the multilevel additionality by creating the indicator which takes into account the sign and significance of treatment effects and the number of outcome variables. Regarding behavioural additionality in Spain, the results suggest a high level of overall complementarity between regional and national policies, but it cannot be deduced if complementarity holds for each cooperative partner individually.

\section{Methodology and data}

\subsection{Empirical strategy}

In assessing the impact of public support, our empirical strategy encompasses the use of a multilevel treatment model, which is motivated by endogeneity of public support due to self-selection of firms into public support and public agencies adopting "picking-the-winner" strategy, as discussed above. Consequently, the effect of public support must be estimated as a treatment assignment, that is, the average treatment on the treated (ATT) effect. We follow the most common approach in this kind of research, which is to match by means of propensity scores participating (treated) firms to non-participating (non-treated) firms with similar characteristics, which thus constitute a comparison group, and then to estimate the difference 
between cooperative behaviour for firms receiving a particular treatment, as the outcome of interest $\left(Y_{1}\right)$, and the outcome for the comparison group of firms $\left(Y_{0}\right)$ (Cerulli 2010). ${ }^{7}$

To safely attribute the estimated difference to a treatment assignment, the treated firms must be similar to the comparison firms in all respects except for the treatment assignment. In turn, this depends on two identifying assumptions: the conditional independence assumption (CIA), or selection on observables, which posits that the outcome in case of no treatment $\left(Y_{0}\right)$ is independent of treatment assignment $(T)$, conditional on covariates $X$ (Imbens 2004; Imbens and Wooldridge 2009); and the overlap or common support condition, whereby the estimated propensity scores take positive values (Heckman and Vytilacil 2007).

Given that regional and national public support are provided simultaneously, we estimate treatment effects in the multiple treatment context. In this way, by estimating a multiple treatment model, we take into account the presence of hidden treatment (Guerzoni and Raiteri 2015), i.e. a simultaneous receipt of both sources of support (policy mix). A matching approach with multiple treatments is first introduced by Lechner (2001) and further elaborated in Lechner (2002a, 2002b). We have M+1 treatments, whereby treatment equal to zero denotes the non-participation in both regional and national support programmes (see e.g. Czarnitzki, Ebersberger, and Fier 2007; Radicic 2019). The average treatment effect on the treated (ATT) effect is then calculated as:

$$
A T T=E\left(Y^{m} \mid T=m\right)-E\left(Y^{l} \mid T=m\right)
$$

Where $m$ denotes the treatment level, $l$ represents the comparison group (the treatment level to which $m$ is compared, termed matched controls by Czarnitzki, Ebersberger, and Fier 2007), and $Y^{m}$ and $Y^{l}$ denote outcomes in states $m$ and $l$ respectively.

We employ the inverse probability of treatment weighting regression adjustment (IPWRA) estimator (Cattaneo 2010). The IPWRA estimator belongs to a group of matching estimators that have the double-robust property. Double robustness implies that either the treatment model or the outcome model (or both) have to be correctly specified for the estimator to produce consistent treatment effects (Hirano, Imbens, and Ridder 2003). The main advantage of the IPWRA estimator is its double robust property. If either the propensity score model (the outcome model) or the treatment model is correctly specified, then this estimator will yield

\footnotetext{
${ }^{7}$ In the case of a binary treatment variable, the matching approach estimates the difference between firms in two states that cannot be observed simultaneously: the treatment state; and the counterfactual state of non-treatment.
} 
treatment effects with a lower bias than will other estimators that are not characterized by the double-robustness property (Linden et al. 2016).

The IPWRA estimator consists of three steps. First, for each firm in the sample, the treatment model estimates the propensity score, which is the probability for each firm of participation in public support (i.e. treatment assignment). Given that we evaluate multiple treatment effects, the propensity scores are estimated by a multinomial logit model, incorporating all four treatment levels: neither regional nor national support; only regional support; only national support; and both. The choice of the model is motivated by the nature of our treatment variable, which has more than two outcomes with no natural ordering. The propensity scores enable firms to be matched within each treatment level. Second, regressions are estimated by the probit model, because the outcome variables are binary indicators, in which the inverse of the estimated propensity scores are used as weights on covariates $X$ and our treatment dummies. Third, from each of these regressions, the ATT effect is computed as the difference in the weighted averages of the predicted outcomes (for technical details, see Wooldridge 2010). This three-step approach provides consistent estimates given the underlying assumption of the independence of the treatment from the predicted outcomes once covariates are modelled in steps 1 and 2. We report valid standard errors (of the Huber/White/sandwich type) which take into account that the estimates are computed in a three-step approach (Emsley et al. 2008).

\subsection{Model specification}

To estimate the individual and joint effects of regional and national public support, we create the treatment variable with the following values: ${ }^{8}$

- treatment $=0$ if a firm did not participate in regional and national public support from 2010-2012 (3,488 SMEs and 321 large firms);

- $\quad$ treatment=1 if a firm participated only in regional public support from 2010-2012 (586 SMEs and 43 large firms);

- $\quad$ treatment=2 if a firm participated only in national public support from 2010-2012 (693 SMEs and 153 large firms);

\footnotetext{
${ }^{8}$ For the sake of brevity, in further text we use the term regional support, but this refers to either local or regional public funding.
} 
- treatment=3 if a firm participated in both regional and national public support from 2010-2012 (277 SMEs and 92 large firms).

Available data allows us to explore how public support affects several types of cooperative relationships: cooperation with customers, suppliers, competitors, consultants, HEIs and government institutions (see e.g. Antonioli, Marzucchi, and Montresor 2014). Therefore, outcome variables are defined as follows (see Table 2 for variable definitions and descriptive statistics):

- Cooperation with consumers: a dummy variable (DV) $=1$ if a firm cooperates with clients or customers, and zero otherwise;

- Cooperation with suppliers: DV=1 if a firm cooperates with suppliers, and zero otherwise;

- Cooperation with competitors: DV=1 if a firm cooperates with competitors or other firms in the sector, and zero otherwise;

- Cooperation with consultants: DV=1 if a firm cooperates with consultants, commercial labs or private R\&D institutes, and zero otherwise;

- Cooperation with HEIs: DV=1 if a firm cooperates with universities or other higher education institutions, and zero otherwise;

- Cooperation with government: DV=1 if a firm cooperates with government or public research institutes, and zero otherwise.

\subsubsection{Control (matching) variables}

To estimate propensity scores from multinomial logit models (step 1 explained in Section 4.1), we include a set of control (or matching) variables. These variables are also included in probit models (step 2) together with the estimated propensity scores from step 1, which are used as weights. To control for firms' absorptive capacity (Cohen and Levinthal 1990), we include the variable Internal $R \& D$, which is a binary indicator equal to 1 if a firm engaged in internal $R \& D$ between 2010 and 2012. We also control for external R\&D (a binary indicator External $R \& D$ ); acquisition of machinery and equipment (a binary indicator Acquisition_machinery); acquisition of existing knowledge from other enterprises or organisations (variable Acquisition_knowledge) (see e.g. Fernández-Ribas and Shapira 2009); training for innovative 
activities (variable Training); market introduction of product innovation (variable Market_introduction) and other innovation expenditures (variable Other expenditure).

Our model also includes a dummy variable for belonging to a group (Group). This variable can capture a twofold effect; a directly positive effect on cooperation, as firms of any size that are a part of the enterprise group could be more likely to cooperate with other firms within a group (Czarnitzki, Ebersberger, and Fier 2007); and/or, an indirect effect via an adverse effect on the probability of receiving support in case of SMEs. Some support measures are restrictive insofar as SMEs that are part of a group are not eligible to apply, this could be, for example, that collectively the group would put them outside of the qualifying definitions of being an SME. Thus, belonging to a group can be a barrier to participation in support programmes (Almus and Czarnitzki 2003).

We model exporting activities (Export) as a binary indicator equal to one if firms export and zero otherwise. Exporting can have a positive impact on cooperation, given that exporters potentially have a larger and/or more diverse network of cooperation partners than do nonexporting firms. Furthermore, exporting firms might have more incentive to innovate as a result of competitive pressure on international markets (Busom and Fernandez-Ribas 2008; Wanzenböck, Scherngell, and Fischer 2013). To account for firms' financial performance, we include the variable that measures firms' growth rate of turnover.

Following the literature on determinants of $\mathrm{R} \& \mathrm{D}$ cooperation (Cassiman and Veugelers 2002; Chun and Mun 2012), we also include the below sources of information as matching variables.

- Internal sources of information, to measure the importance of information within a firm or enterprise group (Info_internal);

- Market sources of information (Info_market): from customers, suppliers, competitors and consultants or, commercial labs;

- Institutional sources (Info_institutional): from universities, government, public or private research institutes; and

- Other sources (Info_others): conferences, trade fairs and exhibitions; scientific journals and trade/technical publications; and professional and industry associations.

All variables are measured as standardized scores from zero to one.

To control for industry heterogeneity, based on the NACE classification at the 2-digit industry level, we include sector dummy variables for the Eurostat aggregation of the 
manufacturing industry according to technological intensity: high-tech; medium-high tech; medium-low tech; and low-tech. (see Table 2 for variable definition). ${ }^{9}$ The base category is the low-tech industry. Finally, in the SME sample, we include a dummy variable for small firms with fewer than 50 employees (see e.g. Marzucchi and Montresor 2015). SMEs are a heterogeneous category, and public support could have a differential effect on small firms relative to medium-sized firms (Curran 2000).

\subsection{Data}

Our study employs Spanish CIS2012 survey data covering the period 2010-2012. Anonymised data in a micro-aggregated form are provided by Eurostat. Several studies use anonymised micro-data: for instance, Mohnen and Hoareau (2003) from the second wave of the CIS; and Grimpe and Sofka (2008) from the third wave of the CIS. Spithoven et al. (2012) use anonymised micro-data from the third CIS wave to analyse five EU countries. In addition, the authors compare the empirical results for Belgium from both the original and the anonymized data and report that 'the results showed very similar parameter estimates' (p. 69).

The full sample consists of 12,177 manufacturing firms. However, due to missing values, the effective sample amounts to 5,653 innovating firms, out of which 5,044 are SMEs with fewer than 250 employees and 609 are large firms. ${ }^{10}$ Small firms are defined as those employing less than 50 workers, while medium-sized firms employ between 50 and 250 workers. A similar portion of SMEs participated in either regional (586 firms or 11.6 per cent) or national programmes (693 firms or 13.7 per cent). Furthermore, 277 SMEs (5.5 per cent) received both regional and national support. Regarding large firms, 43 firms or 7.1 per cent received only regional support, while this proportion is much higher for national support (153 firms or 21.5 per cent) and for both types of support jointly (92 firms or 15.1 per cent).

Descriptive statistics are presented in Table 2. Compared to large firms, SMEs cooperate to a lesser degree with each type of cooperative partners. Regarding specific partners, the largest number of SMEs cooperate with government (14.7 per cent) followed by suppliers (11.4 per cent) and customers (11.1 per cent). The smallest number of SMEs engages in horizontal cooperation with competitors ( 5.9 per cent). Concerning large firms, the percentages

\footnotetext{
${ }^{9}$ There is one discrepancy between the NACE two-digit aggregation and the CIS anonymised microdata because of the anonymization of the data. Namely, sector 20 - Manufacture of chemicals and chemical products is a medium-high tech sector, but is aggregated with six medium low-tech sectors.

${ }^{10} \mathrm{We}$ define innovating firms as those firms that introduced either type of innovation, whether technological (product and process) innovations or non-technological (marketing and organizational) innovations.
} 
for each type of cooperation are at least double compared to SMEs, however the comparison between specific partners reveals a similar pattern to SMEs. Namely, the largest number of large firms reports to cooperate with suppliers (35.3 per cent) and government (35.1 per cent), while the smallest number cooperates with competitors (17.6 per cent).

With respect to innovation activities, 60 per cent of SMEs report to be engaged in inhouse R\&D between 2010 and 2012, while 27.2 per cent also engage in extramural R\&D. One fifth of SMEs acquired machinery, equipment, software or buildings, while 17.2 per cent provided training to its personnel in relation to technological innovations. Slightly more than one fifth of SMEs engaged in market introduction of product innovation, while a very small number of SMEs (1.5 per cent) acquired existing knowledge from other firms. Furthermore, a large number of SMEs are exporters (83 per cent), while slightly more than a third of SMEs belong to an enterprise group. Interestingly, the growth rate between 2010 and 2012 is two times higher in SMEs than in large firms. Among various sources of information, the most important are internal sources (mean value of 0.77 ), followed by market sources of information (the mean value of 0.45 ) and other sources (the mean value of 0.31 ).

Table 3 shows descriptive statistics by firm size and treatment level. Regarding SMEs, the share of firms collaborating with any partner increases as we move from no support to joint support. However, when looking at control (matching) variables, the proportion of firms is quite balanced across treatment levels except for some variables. Specifically, with respect to absorptive capacity, while 50 per cent of SMEs which did not receive support (column 2) engage in internal $R \& D$, this share is larger for firms receiving only regional support (71.8 per cent; column 3), only national support (86.2 per cent; column 4) and both types of support (89.2 per cent; column 5). Similarly, engagement in external R\&D is smallest for untreated firms (18.2 per cent; column 2), and highest for firms receiving both types of support (61 per cent; column 5).

Summary statistics regarding the outcome and matching variables in large firms is qualitatively very similar to that of SMEs. In summing up, we can conclude that treated firms at any treatment level are more likely to collaborate with partners relative to untreated firms, while, except for internal and external R\&D activities, firm characteristics are quite balanced across treatment levels. These features of firms in different categories of treatment levels suggests that matching is a suitable estimation strategy, whereby firms with similar characteristics but at a different treatment level are comparable. 
Table 2. Variable definition, mean and standard deviation of the outcome and control (matching) variables

\begin{tabular}{|c|c|c|c|}
\hline \multirow[b]{2}{*}{ Variable } & \multirow[b]{2}{*}{ Variable definition } & SMEs & $\begin{array}{c}\text { Large } \\
\text { firms }\end{array}$ \\
\hline & & $\begin{array}{c}\text { Mean } \\
\text { (standard } \\
\text { deviation) }\end{array}$ & $\begin{array}{c}\text { Mean } \\
\text { (standard } \\
\text { deviation) }\end{array}$ \\
\hline \multicolumn{4}{|l|}{ Outcome variables } \\
\hline $\begin{array}{l}\text { Cooperation with } \\
\text { customers }\end{array}$ & $\mathrm{DV}=1$ if a firm cooperates with customers in either private or public sector; zero otherwise & $\begin{array}{c}0.111 \\
(0.314) \\
\end{array}$ & $\begin{array}{c}0.233 \\
(0.423) \\
\end{array}$ \\
\hline $\begin{array}{l}\text { Cooperation with } \\
\text { suppliers }\end{array}$ & DV=1 if a firm cooperates with suppliers; zero otherwise & $\begin{array}{c}0.144 \\
(0.351)\end{array}$ & $\begin{array}{c}0.353 \\
(0.478)\end{array}$ \\
\hline $\begin{array}{l}\text { Cooperation with } \\
\text { competitors }\end{array}$ & $\mathrm{DV}=1$ if a firm cooperates with competitors; zero otherwise & $\begin{array}{c}0.059 \\
(0.236) \\
\end{array}$ & $\begin{array}{c}0.176 \\
(0.381) \\
\end{array}$ \\
\hline $\begin{array}{l}\text { Cooperation with } \\
\text { consultants }\end{array}$ & DV=1 if a firm cooperates with consultants or commercial labs; zero otherwise & $\begin{array}{c}0.086 \\
(0.281) \\
\end{array}$ & $\begin{array}{c}0.236 \\
(0.425) \\
\end{array}$ \\
\hline Cooperation with HEIs & DV=1 if a firm cooperates with universities or other higher education institutions (HEIs); zero otherwise & $\begin{array}{c}0.097 \\
(0.296) \\
\end{array}$ & $\begin{array}{c}0.320 \\
(0.467) \\
\end{array}$ \\
\hline $\begin{array}{l}\text { Cooperation with } \\
\text { government }\end{array}$ & DV=1 if a firm cooperates with government, public or private research institutes; zero otherwise & $\begin{array}{c}0.147 \\
(0.354) \\
\end{array}$ & $\begin{array}{c}0.351 \\
(0.478) \\
\end{array}$ \\
\hline \multicolumn{4}{|c|}{ Control (matching) variables } \\
\hline Internal_R\&D & $\begin{array}{l}\text { DV=1 if a firm responded "Yes" to the following question: "During the three years } 2010 \text { to 2012, did your } \\
\text { enterprise engage in the following innovation activities: In-house R\&D"; zero otherwise }\end{array}$ & $\begin{array}{c}0.600 \\
(0.491)\end{array}$ & $\begin{array}{c}0.750 \\
(0.433)\end{array}$ \\
\hline External_R\&D & $\begin{array}{l}\text { DV=1 if a firm responded "Yes" to the following question: "During the three years } 2010 \text { to 2012, did your } \\
\text { enterprise engage in the following innovation activities: External R\&D"; zero otherwise }\end{array}$ & $\begin{array}{c}0.272 \\
(0.445)\end{array}$ & $\begin{array}{c}0.506 \\
(0.500)\end{array}$ \\
\hline Acquisition_machinery & $\begin{array}{l}\text { DV=1 if a firm responded "Yes" to the following question: "During the three years } 2010 \text { to } 2012 \text {, did your } \\
\text { enterprise engage in the following innovation activities: Acquisition of machinery, equipment, software \& } \\
\text { buildings"; zero otherwise }\end{array}$ & $\begin{array}{c}0.211 \\
(0.408)\end{array}$ & $\begin{array}{c}0.312 \\
(0.464)\end{array}$ \\
\hline Acquisition_knowledge & $\begin{array}{l}\text { DV=1 if a firm responded "Yes" to the following question: "During the three years } 2010 \text { to 2012, did your } \\
\text { enterprise engage in the following innovation activities: Acquisition of existing } \\
\text { knowledge from other enterprises or organisations"; zero otherwise }\end{array}$ & $\begin{array}{c}0.015 \\
(0.123)\end{array}$ & $\begin{array}{c}0.046 \\
(0.210)\end{array}$ \\
\hline Training & $\begin{array}{l}\text { DV=1 if a firm responded "Yes" to the following question: "During the three years } 2010 \text { to 2012, did your } \\
\text { enterprise engage in the following innovation activities: Training for innovative activities"; zero otherwise }\end{array}$ & $\begin{array}{c}0.172 \\
(0.377) \\
\end{array}$ & $\begin{array}{c}0.243 \\
(0.429)\end{array}$ \\
\hline Market_introduction & $\begin{array}{l}\text { DV=1 if a firm responded "Yes" to the following question: "During the three years } 2010 \text { to } 2012 \text {, did your } \\
\text { enterprise engage in the following innovation activities: Market introduction of innovations"; zero otherwise }\end{array}$ & $\begin{array}{c}0.231 \\
(0.421)\end{array}$ & $\begin{array}{c}0.363 \\
(0.481) \\
\end{array}$ \\
\hline Other_expenditure & $\begin{array}{l}\mathrm{DV}=1 \text { if a firm responded "Yes" to the following question: "During the three years } 2010 \text { to } 2012 \text {, did your } \\
\text { enterprise engage in the following innovation activities: Other (such as feasibility studies, testing, tooling up, } \\
\text { industrial engineering, etc."; zero otherwise }\end{array}$ & $\begin{array}{c}0.079 \\
(0.270)\end{array}$ & $\begin{array}{c}0.126 \\
(0.333)\end{array}$ \\
\hline
\end{tabular}




\begin{tabular}{|c|c|c|c|}
\hline Group & $\mathrm{DV}=1$ if a firm belongs to enterprise group; zero otherwise & $\begin{array}{c}0.342 \\
(0.474)\end{array}$ & $\begin{array}{c}0.893 \\
(0.309)\end{array}$ \\
\hline Export & $\mathrm{DV}=1$ if a firm is an exporter; zero otherwise & $\begin{array}{c}0.830 \\
(0.375)\end{array}$ & $\begin{array}{c}0.923 \\
(0.267)\end{array}$ \\
\hline Turnover_growth & The growth rate of turnover between 2010 and 2012 & $\begin{array}{c}0.163 \\
(2.002)\end{array}$ & $\begin{array}{c}0.081 \\
(0.458)\end{array}$ \\
\hline Info_internal & Importance of information from the firm or enterprise group (a standardized score between 0 and 1 ) & $\begin{array}{c}0.765 \\
(0.324)\end{array}$ & $\begin{array}{c}0.858 \\
(0.269) \\
\end{array}$ \\
\hline Info_market & $\begin{array}{l}\text { Importance of following sources of information: customers, suppliers, competitors, consultants and commercial } \\
\text { labs (a standardized score between } 0 \text { and } 1 \text { ) }\end{array}$ & $\begin{array}{c}0.447 \\
(0.266)\end{array}$ & $\begin{array}{c}0.521 \\
(0.255)\end{array}$ \\
\hline Info_institutional & $\begin{array}{l}\text { Importance of universities (and other higher education institutions -HEIs), government, public or private } \\
\text { research institutes as a source of information (a standardized score between } 0 \text { and } 1 \text { ) }\end{array}$ & $\begin{array}{c}0.252 \\
(0.294)\end{array}$ & $\begin{array}{c}0.407 \\
(0.320) \\
\end{array}$ \\
\hline Info_others & $\begin{array}{l}\text { Importance of following sources of information: conferences, trade fairs and exhibitions; scientific journals and } \\
\text { trade/technical publications; and professional and industry associations (a standardized score between } 0 \text { and } 1 \text { ) }\end{array}$ & $\begin{array}{c}0.308 \\
(0.274)\end{array}$ & $\begin{array}{c}0.390 \\
(0.272) \\
\end{array}$ \\
\hline High tech & $\begin{array}{l}\mathrm{DV}=1 \text { if a firm operates in NACE Rev.2 sectors: 21-Manufacture of basic pharmaceutical products and } \\
\text { pharmaceutical preparations; or 26-Manufacture of computer, electronic and optical products; and zero } \\
\text { otherwise }\end{array}$ & $\begin{array}{c}0.069 \\
(0.253)\end{array}$ & $\begin{array}{c}0.115 \\
(0.319)\end{array}$ \\
\hline Medium high tech & $\begin{array}{l}\text { DV=1 if a firm is in NACE Rev.2 sectors: 28-Manufacture of machinery and equipment n.e.c.; 29-Manufacture } \\
\text { of motor vehicles, trailers and semi-trailers; or 30-Manufacture of other transport equipment; and zero otherwise }\end{array}$ & $\begin{array}{c}0.218 \\
(0.413)\end{array}$ & $\begin{array}{c}0.263 \\
(0.440)\end{array}$ \\
\hline Medium low tech & $\begin{array}{l}\text { DV=1 if a firm is in NACE Rev.2 sectors: 19-Manufacture of coke and refined petroleum products; } 20 \text { - } \\
\text { Manufacture of chemicals and chemical products; } 27-\text { Manufacture of electrical equipment; 22-Manufacture of } \\
\text { rubber and plastic products; } 23 \text {-Manufacture of other non-metallic mineral products; } 24-\text { Manufacture of basic } \\
\text { metals; } 25 \text {-Manufacture of fabricated metals products, excepts machinery and equipment; or 33-Repair and } \\
\text { installation of machinery and equipment; and zero otherwise }\end{array}$ & $\begin{array}{c}0.377 \\
(0.485)\end{array}$ & $\begin{array}{c}0.294 \\
(0.456)\end{array}$ \\
\hline $\begin{array}{l}\text { Low tech (base } \\
\text { category) }\end{array}$ & $\begin{array}{l}\text { DV=1 if a firm is in NACE Rev.2 sectors: 10-Manufacture of food products; 11-Manufacture of beverages; } \\
\text { 12-Manufacture of tobacco products; 13-Manufacture of textile; 14-Manufacture of wearing apparel; } 15- \\
\text { Manufacture of leather and related products; 16-Manufacture of wood and of products of wood; 17- } \\
\text { Manufacture of paper and paper products; 18- Printing and reproduction of recorded media; } 31 \text {-Manufacture } \\
\text { of furniture; or 32-Other manufacturing; and zero otherwise }\end{array}$ & $\begin{array}{c}(0.336) \\
0.473\end{array}$ & $\begin{array}{c}0.328 \\
(0.470)\end{array}$ \\
\hline
\end{tabular}


Table 3. Summary statistics (mean and standard deviation in parentheses) by treatment level and firm size

\begin{tabular}{|c|c|c|c|c|c|c|c|c|}
\hline \multirow[b]{2}{*}{ Variables } & \multicolumn{4}{|c|}{ SMEs } & \multicolumn{4}{|c|}{ Large firms } \\
\hline & $\begin{array}{c}\text { No support } \\
\text { (treatment=0) } \\
\quad \mathrm{N}=\mathbf{3 , 4 8 8}\end{array}$ & $\begin{array}{c}\text { Only regional } \\
\text { support } \\
\text { (treatment=1) } \\
\quad \mathrm{N}=586\end{array}$ & $\begin{array}{l}\text { Only national } \\
\text { support } \\
\text { (treatment=2) } \\
\quad \mathrm{N}=693\end{array}$ & $\begin{array}{l}\text { Both regional } \\
\text { and national } \\
\text { support } \\
\text { (treatment=3) } \\
\quad \mathrm{N}=277\end{array}$ & $\begin{array}{c}\text { No support } \\
\text { (treatment=0) } \\
\mathbf{N}=\mathbf{3 2 1}\end{array}$ & $\begin{array}{l}\text { Only regional } \\
\text { support } \\
\text { (treatment=1) } \\
\quad \mathrm{N}=43\end{array}$ & $\begin{array}{l}\text { Only national } \\
\text { support } \\
\text { (treatment=2) } \\
\quad \mathrm{N}=153\end{array}$ & $\begin{array}{c}\text { Both regional } \\
\text { and national } \\
\text { support } \\
\text { (treatment=3) } \\
\quad \mathrm{N}=92\end{array}$ \\
\hline \multicolumn{9}{|l|}{ Outcome variables } \\
\hline $\begin{array}{l}\text { Cooperation with } \\
\text { customers }\end{array}$ & $\begin{array}{c}0.071 \\
(0.257)\end{array}$ & $\begin{array}{c}0.152 \\
(0.359)\end{array}$ & $\begin{array}{c}0.190 \\
(0.393)\end{array}$ & $\begin{array}{c}0.392 \\
(0.471)\end{array}$ & $\begin{array}{c}0.118 \\
(0.324)\end{array}$ & $\begin{array}{c}0.163 \\
(0.374)\end{array}$ & $\begin{array}{c}0.333 \\
(0.473)\end{array}$ & $\begin{array}{c}0.500 \\
(0.503)\end{array}$ \\
\hline $\begin{array}{l}\text { Cooperation with } \\
\text { suppliers }\end{array}$ & $\begin{array}{c}0.101 \\
(0.302)\end{array}$ & $\begin{array}{c}0.191 \\
(0.394) \\
\end{array}$ & $\begin{array}{c}0.241 \\
(0.428) \\
\end{array}$ & $\begin{array}{c}0.343 \\
(0.476) \\
\end{array}$ & $\begin{array}{c}0.209 \\
(0.407)\end{array}$ & $\begin{array}{c}0.372 \\
(0.489) \\
\end{array}$ & $\begin{array}{c}0.490 \\
(0.502) \\
\end{array}$ & $\begin{array}{c}0.620 \\
(0.488)\end{array}$ \\
\hline $\begin{array}{l}\text { Cooperation with } \\
\text { competitors }\end{array}$ & $\begin{array}{c}0.036 \\
(0.185) \\
\end{array}$ & $\begin{array}{c}0.096 \\
(0.294) \\
\end{array}$ & $\begin{array}{c}0.114 \\
(0.318) \\
\end{array}$ & $\begin{array}{c}0.141 \\
(0.348) \\
\end{array}$ & $\begin{array}{c}0.069 \\
(0.253) \\
\end{array}$ & $\begin{array}{c}0.140 \\
(0.351) \\
\end{array}$ & $\begin{array}{c}0.275 \\
(0.448) \\
\end{array}$ & $\begin{array}{c}0.402 \\
(0.493) \\
\end{array}$ \\
\hline $\begin{array}{l}\text { Cooperation with } \\
\text { consultants }\end{array}$ & $\begin{array}{c}0.052 \\
(0.221)\end{array}$ & $\begin{array}{c}0.147 \\
(0.354)\end{array}$ & $\begin{array}{c}0.150 \\
(0.357)\end{array}$ & $\begin{array}{c}0.238 \\
(0.427)\end{array}$ & $\begin{array}{c}0.112 \\
(0.316)\end{array}$ & $\begin{array}{c}0.233 \\
(0.427)\end{array}$ & $\begin{array}{c}0.346 \\
(0.477)\end{array}$ & $\begin{array}{c}0.489 \\
(0.503)\end{array}$ \\
\hline Cooperation with HEIs & $\begin{array}{c}0.050 \\
(0.219) \\
\end{array}$ & $\begin{array}{l}0.135 \\
(0.342) \\
\end{array}$ & $\begin{array}{c}0.218 \\
(0.413) \\
\end{array}$ & $\begin{array}{c}0.303 \\
(0.460) \\
\end{array}$ & $\begin{array}{c}0.171 \\
(0.377) \\
\end{array}$ & $\begin{array}{c}0.372 \\
(0.489)\end{array}$ & $\begin{array}{l}0.425 \\
(0.496) \\
\end{array}$ & $\begin{array}{c}0.641 \\
(0.482)\end{array}$ \\
\hline $\begin{array}{l}\text { Cooperation with } \\
\text { government }\end{array}$ & $\begin{array}{c}0.074 \\
(0.261) \\
\end{array}$ & $\begin{array}{c}0.282 \\
(0.450) \\
\end{array}$ & $\begin{array}{c}0.278 \\
(0.448) \\
\end{array}$ & $\begin{array}{c}0.455 \\
(0.499) \\
\end{array}$ & $\begin{array}{c}0.153 \\
(0.360) \\
\end{array}$ & $\begin{array}{c}0.512 \\
(0.506) \\
\end{array}$ & $\begin{array}{c}0.523 \\
(0.501) \\
\end{array}$ & $\begin{array}{c}0.685 \\
(0.467) \\
\end{array}$ \\
\hline \multicolumn{9}{|c|}{ Control (matching) variables } \\
\hline Internal_R\&D & $\begin{array}{c}0.500 \\
(0.500)\end{array}$ & $\begin{array}{c}0.718 \\
(0.450)\end{array}$ & $\begin{array}{c}0.862 \\
(0.345)\end{array}$ & $\begin{array}{c}0.892 \\
(0.311)\end{array}$ & $\begin{array}{c}0.607 \\
(0.489)\end{array}$ & $\begin{array}{c}0.791 \\
(0.412)\end{array}$ & $\begin{array}{c}0.908 \\
(0.289)\end{array}$ & $\begin{array}{c}0.967 \\
(0.179)\end{array}$ \\
\hline External_R\&D & $\begin{array}{c}0.182 \\
(0.386)\end{array}$ & $\begin{array}{c}0.413 \\
(0.493)\end{array}$ & $\begin{array}{c}0.468 \\
(0.499)\end{array}$ & $\begin{array}{c}0.610 \\
(0.489)\end{array}$ & $\begin{array}{c}0.330 \\
(0.471)\end{array}$ & $\begin{array}{c}0.558 \\
(0.502)\end{array}$ & $\begin{array}{c}0.706 \\
(0.457)\end{array}$ & $\begin{array}{c}0.761 \\
(0.429)\end{array}$ \\
\hline Acquisition_machinery & $\begin{array}{c}0.203 \\
(0.402) \\
\end{array}$ & $\begin{array}{c}0.235 \\
(0.425) \\
\end{array}$ & $\begin{array}{c}0.226 \\
(0.419) \\
\end{array}$ & $\begin{array}{c}0.220 \\
(0.415) \\
\end{array}$ & $\begin{array}{c}0.262 \\
(0.440) \\
\end{array}$ & $\begin{array}{c}0.302 \\
(0.465) \\
\end{array}$ & $\begin{array}{c}0.269 \\
(0.481) \\
\end{array}$ & $\begin{array}{c}0.413 \\
(0.495) \\
\end{array}$ \\
\hline Acquisition_knowledge & $\begin{array}{c}0.012 \\
(0.108) \\
\end{array}$ & $\begin{array}{c}0.020 \\
(0.142) \\
\end{array}$ & $\begin{array}{c}0.023 \\
(0.150) \\
\end{array}$ & $\begin{array}{c}0.029 \\
(0.168) \\
\end{array}$ & $\begin{array}{c}0.034 \\
(0.182) \\
\end{array}$ & $\begin{array}{c}0.047 \\
(0.213) \\
\end{array}$ & $\begin{array}{c}0.072 \\
(0.259) \\
\end{array}$ & $\begin{array}{c}0.043 \\
(0.205) \\
\end{array}$ \\
\hline Training & $\begin{array}{c}0.164 \\
(0.370)\end{array}$ & $\begin{array}{c}0.164 \\
(0.370)\end{array}$ & $\begin{array}{c}0.179 \\
(0.383)\end{array}$ & $\begin{array}{c}0.271 \\
(0.445)\end{array}$ & $\begin{array}{c}0.168 \\
(0.375)\end{array}$ & $\begin{array}{c}0.186 \\
(0.394)\end{array}$ & $\begin{array}{c}0.366 \\
(0.483)\end{array}$ & $\begin{array}{c}0.326 \\
(0.471)\end{array}$ \\
\hline Market_introduction & $\begin{array}{c}0.210 \\
(0.407)\end{array}$ & $\begin{array}{c}0.244 \\
(0.430)\end{array}$ & $\begin{array}{c}0.287 \\
(0.453)\end{array}$ & $\begin{array}{c}0.325 \\
(0.469)\end{array}$ & $\begin{array}{c}0.330 \\
(0.471)\end{array}$ & $\begin{array}{c}0.302 \\
(0.465)\end{array}$ & $\begin{array}{c}0.359 \\
(0.481)\end{array}$ & $\begin{array}{c}0.511 \\
(0.503)\end{array}$ \\
\hline Other_expenditure & $\begin{array}{c}0.068 \\
(0.251)\end{array}$ & $\begin{array}{c}0.101 \\
(0.301)\end{array}$ & $\begin{array}{c}0.099 \\
(0.299)\end{array}$ & $\begin{array}{c}0.126 \\
(0.333)\end{array}$ & $\begin{array}{c}0.090 \\
(0.287)\end{array}$ & $\begin{array}{c}0.186 \\
(0.394)\end{array}$ & $\begin{array}{c}0.203 \\
(0.403)\end{array}$ & $\begin{array}{c}0.098 \\
(0.299)\end{array}$ \\
\hline
\end{tabular}




\begin{tabular}{|c|c|c|c|c|c|c|c|c|}
\hline Group & $\begin{array}{c}0.317 \\
(0.466) \\
\end{array}$ & $\begin{array}{c}0.326 \\
(0.469) \\
\end{array}$ & $\begin{array}{c}0.419 \\
(0.494) \\
\end{array}$ & $\begin{array}{c}0.484 \\
(0.501)\end{array}$ & $\begin{array}{c}0.882 \\
(0.324) \\
\end{array}$ & $\begin{array}{c}0.860 \\
(0.351) \\
\end{array}$ & $\begin{array}{c}0.915 \\
(0.280) \\
\end{array}$ & $\begin{array}{c}0.913 \\
(0.283) \\
\end{array}$ \\
\hline Export & $\begin{array}{c}0.805 \\
(0.396)\end{array}$ & $\begin{array}{c}0.855 \\
(0.352)\end{array}$ & $\begin{array}{c}0.899 \\
(0.301)\end{array}$ & $\begin{array}{c}0.921 \\
(0.271)\end{array}$ & $\begin{array}{c}0.888 \\
(0.316)\end{array}$ & $\begin{array}{c}0.930 \\
(0.258)\end{array}$ & $\begin{array}{c}0.961 \\
(0.195)\end{array}$ & $\begin{array}{c}0.978 \\
(0.147)\end{array}$ \\
\hline Turnover_growth & $\begin{array}{c}0.119 \\
(1.146)\end{array}$ & $\begin{array}{c}0.319 \\
(4.864)\end{array}$ & $\begin{array}{c}0.168 \\
(0.808)\end{array}$ & $\begin{array}{c}0.375 \\
(2.177)\end{array}$ & $\begin{array}{c}0.058 \\
(0.394)\end{array}$ & $\begin{array}{c}0.074 \\
(0.418)\end{array}$ & $\begin{array}{c}0.144 \\
(0.596)\end{array}$ & $\begin{array}{c}0.061 \\
(0.415)\end{array}$ \\
\hline Info_internal & $\begin{array}{c}0.740 \\
(0.342)\end{array}$ & $\begin{array}{c}0.808 \\
(0.276)\end{array}$ & $\begin{array}{c}0.820 \\
(0.278)\end{array}$ & $\begin{array}{c}0.848 \\
(0.243)\end{array}$ & $\begin{array}{c}0.816 \\
(0.317)\end{array}$ & $\begin{array}{c}0.915 \\
(0.207)\end{array}$ & $\begin{array}{c}0.887 \\
(0.206)\end{array}$ & $\begin{array}{c}0.931 \\
(0.153)\end{array}$ \\
\hline Info_market & $\begin{array}{c}0.410 \\
(0.266)\end{array}$ & $\begin{array}{c}0.512 \\
(0.255)\end{array}$ & $\begin{array}{c}0.522 \\
(0.245)\end{array}$ & $\begin{array}{c}0.585 \\
(0.229)\end{array}$ & $\begin{array}{c}0.440 \\
(0.265)\end{array}$ & $\begin{array}{c}0.537 \\
(0.244)\end{array}$ & $\begin{array}{c}0.602 \\
(0.209)\end{array}$ & $\begin{array}{c}0.660 \\
(0.182) \\
\end{array}$ \\
\hline Info_institutional & $\begin{array}{c}0.191 \\
(0.264) \\
\end{array}$ & $\begin{array}{c}0.335 \\
(0.300) \\
\end{array}$ & $\begin{array}{c}0.401 \\
(0.315) \\
\end{array}$ & $\begin{array}{c}0.480 \\
(0.303) \\
\end{array}$ & $\begin{array}{c}0.274 \\
(0.281) \\
\end{array}$ & $\begin{array}{c}0.422 \\
(0.296) \\
\end{array}$ & $\begin{array}{c}0.560 \\
(0.283) \\
\end{array}$ & $\begin{array}{c}0.612 \\
(0.294) \\
\end{array}$ \\
\hline Info_others & $\begin{array}{c}0.277 \\
(0.269)\end{array}$ & $\begin{array}{c}0.352 \\
(0.268)\end{array}$ & $\begin{array}{c}0.367 \\
(0.278)\end{array}$ & $\begin{array}{c}0.445 \\
(0.255)\end{array}$ & $\begin{array}{c}0.322 \\
(0.269)\end{array}$ & $\begin{array}{c}0.370 \\
(0.269)\end{array}$ & $\begin{array}{c}0.476 \\
(0.259)\end{array}$ & $\begin{array}{c}0.490 \\
(0.235)\end{array}$ \\
\hline High tech & $\begin{array}{c}0.056 \\
(0.230)\end{array}$ & $\begin{array}{c}0.056 \\
(0.231)\end{array}$ & $\begin{array}{c}0.108 \\
(0.311)\end{array}$ & $\begin{array}{c}0.155 \\
(0.363)\end{array}$ & $\begin{array}{c}0.112 \\
(0.316)\end{array}$ & $\begin{array}{c}0.023 \\
(0.152)\end{array}$ & $\begin{array}{c}0.164 \\
(0.371)\end{array}$ & $\begin{array}{c}0.087 \\
(0.283)\end{array}$ \\
\hline Medium high tech & $\begin{array}{c}0.208 \\
(0.406)\end{array}$ & $\begin{array}{c}0.251 \\
(0.434)\end{array}$ & $\begin{array}{c}0.219 \\
(0.414)\end{array}$ & $\begin{array}{c}0.274 \\
(0.447)\end{array}$ & $\begin{array}{c}0.212 \\
(0.409)\end{array}$ & $\begin{array}{c}0.396 \\
(0.495)\end{array}$ & $\begin{array}{c}0.209 \\
(0.408)\end{array}$ & $\begin{array}{c}0.468 \\
(0.502)\end{array}$ \\
\hline Medium low tech & $\begin{array}{c}0.380 \\
(0.486)\end{array}$ & $\begin{array}{c}0.372 \\
(0.484)\end{array}$ & $\begin{array}{c}0.379 \\
(0.485)\end{array}$ & $\begin{array}{c}0.336 \\
(0.473)\end{array}$ & $\begin{array}{c}0.274 \\
(0.447)\end{array}$ & $\begin{array}{c}0.302 \\
(0.465)\end{array}$ & $\begin{array}{c}0.333 \\
(0.473)\end{array}$ & $\begin{array}{c}0.293 \\
(0.458) \\
\end{array}$ \\
\hline Low tech & $\begin{array}{c}0.356 \\
(0.479)\end{array}$ & $\begin{array}{c}0.321 \\
(0.467)\end{array}$ & $\begin{array}{c}0.294 \\
(0.456)\end{array}$ & $\begin{array}{c}0.235 \\
(0.425)\end{array}$ & $\begin{array}{c}0.402 \\
(0.491)\end{array}$ & $\begin{array}{c}0.279 \\
(0.454)\end{array}$ & $\begin{array}{c}0.294 \\
(0.457)\end{array}$ & $\begin{array}{c}0.152 \\
(0.361)\end{array}$ \\
\hline
\end{tabular}




\section{Results}

Figures A1 and A2 in Appendix show the common support regions at different levels of treatment for SMEs and large firms respectively. Treatment effects of any matching estimator based on the propensity score are only estimated in the region of common support (see Section 4.1). Thus, it is necessary to check the overlap of the propensity scores at different treatment levels. The overlap plots, reported in Figures A1 and A2, reveal that the predicted probabilities are not concentrated near 0 or 1 , which implies that the overlap assumption is not violated (Cattaneo, Drukker, and Holland 2013).

Table A1 in Appendix reports results from a multinomial logit model for one outcome variable - Cooperation with customers, as an example; the base is treatment at level 0 (no participation in regional and national public support). ${ }^{11}$ Table A1 also reports the treatment (selection) model, which is the same for all outcome variables. The treatment model depicts the effects of covariates on the probabilities of different levels of treatment, while the outcome model estimates the impact of covariates on some particular type of cooperative partner (in Table A1, cooperation with customers). Given that the purpose of specifying the model is to facilitate the estimation of treatment effects, the coefficients in the models are not of interest in themselves (Cattaneo, Drukker, and Holland 2013).

Table 4 shows the estimated ATTs for SMEs. First we interpret the absolute effects, estimated in models in which the control group comprises firms that did not receive either regional or national funding. Both regional support (column 2) and national support (column 3) have positive effects on all types of cooperation compared to those firms that did not receive either. Column 4 shows the joint effect of both regional and national support. These joint effects are all positive and highly significant (except for cooperation with competitors, for which $p<0.10$ ) compared to firms with no support.

\footnotetext{
${ }^{11}$ Results for the other multinomial logit models (with the other outcome variables) are not reported but are available on request.
} 
Table 4. The estimated average treatment effects on the treated (ATTs) for SMEs.

\begin{tabular}{|c|c|c|c|c|c|c|}
\hline \multirow[b]{2}{*}{ Outcome variables } & \multicolumn{3}{|c|}{ Absolute effects } & \multicolumn{3}{|c|}{ Relative effects } \\
\hline & $\begin{array}{l}\text { Regional } \\
\text { support vs } \\
\text { no support }\end{array}$ & $\begin{array}{c}\text { National } \\
\text { support vs } \\
\text { no support }\end{array}$ & $\begin{array}{l}\text { Both regional } \\
\text { and national } \\
\text { support vs no } \\
\text { support }\end{array}$ & $\begin{array}{l}\text { Regional } \\
\text { support vs } \\
\text { national } \\
\text { support }\end{array}$ & $\begin{array}{l}\text { Both regional } \\
\text { and national } \\
\text { support vs } \\
\text { regional } \\
\text { support }\end{array}$ & $\begin{array}{c}\text { Both regional } \\
\text { and national } \\
\text { support vs } \\
\text { national } \\
\text { support }\end{array}$ \\
\hline $\begin{array}{l}\text { Cooperation with } \\
\text { customers }\end{array}$ & $\begin{array}{c}0.040 * * \\
(0.016)\end{array}$ & $\begin{array}{l}0.060 * * * \\
(0.017)\end{array}$ & $\begin{array}{l}0.157 * * * \\
(0.031)\end{array}$ & $\begin{array}{l}-0.013 \\
(0.020)\end{array}$ & $\begin{array}{c}0.107 * * * \\
(0.036)\end{array}$ & $\begin{array}{c}0.080 * * \\
(0.033)\end{array}$ \\
\hline $\begin{array}{l}\text { Cooperation with } \\
\text { suppliers }\end{array}$ & $\begin{array}{l}0.057 * * * \\
(0.018)\end{array}$ & $\begin{array}{c}0.093 * * * \\
(0.018)\end{array}$ & $\begin{array}{l}0.178 * * * \\
(0.031)\end{array}$ & $\begin{array}{l}-0.030 \\
(0.022)\end{array}$ & $\begin{array}{c}0.088 * * \\
(0.037)\end{array}$ & $\begin{array}{c}0.053 \\
(0.033)\end{array}$ \\
\hline $\begin{array}{l}\text { Cooperation with } \\
\text { competitors }\end{array}$ & $\begin{array}{c}0.030 * * \\
(0.014)\end{array}$ & $\begin{array}{c}0.035 * * \\
(0.015)\end{array}$ & $\begin{array}{l}0.046^{*} \\
(0.024)\end{array}$ & $\begin{array}{l}-0.007 \\
(0.017)\end{array}$ & $\begin{array}{c}0.017 \\
(0.028)\end{array}$ & $\begin{array}{c}0.015 \\
(0.025)\end{array}$ \\
\hline $\begin{array}{l}\text { Cooperation with } \\
\text { HEIs }\end{array}$ & $\begin{array}{l}0.027 * \\
(0.015)\end{array}$ & $\begin{array}{c}0.072 * * * \\
(0.018)\end{array}$ & $\begin{array}{l}0.106 * * * \\
(0.030)\end{array}$ & $\begin{array}{l}-0.035^{*} \\
(0.018)\end{array}$ & $\begin{array}{c}0.087 * * \\
(0.034)\end{array}$ & $\begin{array}{c}0.021 \\
(0.031)\end{array}$ \\
\hline $\begin{array}{l}\text { Cooperation with } \\
\text { government }\end{array}$ & $\begin{array}{c}0.147 * * * \\
(0.019)\end{array}$ & $\begin{array}{c}0.107 * * * \\
(0.020)\end{array}$ & $\begin{array}{c}0.235^{* * * *} \\
(0.032)\end{array}$ & $\begin{array}{c}0.055^{* *} \\
(0.023)\end{array}$ & $\begin{array}{c}0.060 \\
(0.037)\end{array}$ & $\begin{array}{c}0.134 * * * \\
(0.033)\end{array}$ \\
\hline $\begin{array}{l}\text { Cooperation with } \\
\text { consultants }\end{array}$ & $\begin{array}{c}0.065 * * * \\
(0.016)\end{array}$ & $\begin{array}{c}0.054 * * * \\
(0.016)\end{array}$ & $\begin{array}{c}0.116 * * * \\
(0.028)\end{array}$ & $\begin{array}{c}0.026 \\
(0.019)\end{array}$ & $\begin{array}{c}0.039 \\
(0.033)\end{array}$ & $\begin{array}{c}0.064 * * \\
(0.030)\end{array}$ \\
\hline
\end{tabular}

Notes: Abadie-Imbens (2006) standard errors in parentheses. ${ }^{* * *} p<0.01,{ }^{* *} p<0.05, * p<0.10$. 
To explore which level of support is more effective in fostering cooperative behaviour in Spanish manufacturing SMEs, we estimate the relative effects (Table 4): regional support versus national support (column 5); both regional and national support versus regional support (column 6); and both regional and national support versus national support (column 7). Regional support is more effective in promoting cooperation with government than national support $(p<0.05)$, but this pattern is not found for other cooperative ties (for cooperation with HEIs, we found a marginally negative effect $(p<0.10)$, meaning that regional support is less effective than national support in fostering cooperative ties with HEIs). Results in column 6 show that the joint support is more effective than regional support for vertical cooperation with customers $(p<0.01)$ and suppliers $(p<0.05)$, and for cooperation with HEIs $(p<0.05)$. The estimated treatment effects in column 7 indicate, relative to national support, the joint support is more effective in cooperation with customers $(p<0.05)$, government agencies $(p<0.01)$ and consultants $(p<0.05)$.

Table 5 shows the estimated ATTs for large firms. With respect to the absolute effects, national support increases the probability of cooperation with all partners other than HEIs (column 2), while regional support only positively affects cooperation with HEIs (marginally at the $10 \%$ level of significance) and cooperation with government $(\mathrm{p}<0.01)($ column 1$)$. Column 3 shows that the joint effects of both sources of funding are positive and statistically significant at either $1 \%$ or $5 \%$ level for each type of cooperation.

The estimated relative effects show that the effectiveness of regional support is statistically no different from the effectiveness of national support for all cooperative partners (column 5). Concerning the effects of the joint support relative to regional support (column 6), they are positive and significant $(\mathrm{p}<0.05)$ for cooperation with customers and with competitors and marginally significant $(\mathrm{p}<0.10)$ for cooperation with consultants. Estimated relative effects in column 7 show that the same effectiveness of the joint support and national support. In other words, receiving regional support together with national support is no more effective in facilitating cooperation behaviour in large firms than only receiving national support. 
Table 5. The estimated ATTs for large firms

\begin{tabular}{|c|c|c|c|c|c|c|}
\hline \multirow[b]{2}{*}{ Outcome variables } & \multicolumn{3}{|c|}{ Absolute effects } & \multicolumn{3}{|c|}{ Relative effects } \\
\hline & $\begin{array}{c}\text { Regional } \\
\text { support vs } \\
\text { no support }\end{array}$ & $\begin{array}{c}\text { National } \\
\text { support vs } \\
\text { no support }\end{array}$ & $\begin{array}{c}\text { Both regional } \\
\text { and national } \\
\text { support vs no } \\
\text { support }\end{array}$ & $\begin{array}{c}\text { Regional } \\
\text { support vs } \\
\text { national } \\
\text { support }\end{array}$ & $\begin{array}{c}\text { Both regional } \\
\text { and national } \\
\text { support vs } \\
\text { regional } \\
\text { support } \\
\end{array}$ & $\begin{array}{c}\text { Both regional } \\
\text { and national } \\
\text { support vs } \\
\text { national } \\
\text { support } \\
\end{array}$ \\
\hline $\begin{array}{l}\text { Cooperation with } \\
\text { customers }\end{array}$ & $\begin{array}{l}-0.010 \\
(0.065)\end{array}$ & $\begin{array}{l}0.149 * * * \\
(0.051)\end{array}$ & $\begin{array}{c}0.194 * * \\
(0.076)\end{array}$ & $\begin{array}{l}-0.113 \\
(0.079)\end{array}$ & $\begin{array}{l}0.202 * * \\
(0.091)\end{array}$ & $\begin{array}{c}0.008 \\
(0.066)\end{array}$ \\
\hline $\begin{array}{l}\text { Cooperation with } \\
\text { suppliers }\end{array}$ & $\begin{array}{c}0.086 \\
(0.079)\end{array}$ & $\begin{array}{l}0.151 * * \\
(0.062)\end{array}$ & $\begin{array}{c}0.179 * * \\
(0.079)\end{array}$ & $\begin{array}{l}-0.092 \\
(0.087)\end{array}$ & $\begin{array}{c}0.097 \\
(0.113)\end{array}$ & $\begin{array}{l}-0.003 \\
(0.065)\end{array}$ \\
\hline $\begin{array}{l}\text { Cooperation with } \\
\text { competitors }\end{array}$ & $\begin{array}{c}0.062 \\
(0.057)\end{array}$ & $\begin{array}{l}0.144 * * * \\
(0.047)\end{array}$ & $\begin{array}{c}0.275^{* * *} * \\
(0.064)\end{array}$ & $\begin{array}{l}-0.068 \\
(0.069)\end{array}$ & $\begin{array}{c}0.218 * * \\
(0.092)\end{array}$ & $\begin{array}{c}0.041 \\
(0.074)\end{array}$ \\
\hline $\begin{array}{l}\text { Cooperation with } \\
\text { HEIs }\end{array}$ & $\begin{array}{l}0.120 * \\
(0.072)\end{array}$ & $\begin{array}{c}0.026 \\
(0.056)\end{array}$ & $\begin{array}{c}0.210 * * * \\
(0.069)\end{array}$ & $\begin{array}{c}0.087 \\
(0.075)\end{array}$ & $\begin{array}{c}0.000 \\
(0.089)\end{array}$ & $\begin{array}{c}0.096 \\
(0.061)\end{array}$ \\
\hline $\begin{array}{l}\text { Cooperation with } \\
\text { government }\end{array}$ & $\begin{array}{c}0.245^{* * *} * \\
(0.084)\end{array}$ & $\begin{array}{c}0.169 * * * \\
(0.062)\end{array}$ & $\begin{array}{l}0.311 * * * \\
(0.077)\end{array}$ & $\begin{array}{c}0.123 \\
(0.076)\end{array}$ & $\begin{array}{c}0.019 \\
(0.103)\end{array}$ & $\begin{array}{c}0.098 \\
(0.074)\end{array}$ \\
\hline $\begin{array}{l}\text { Cooperation with } \\
\text { consultants }\end{array}$ & $\begin{array}{c}0.086 \\
(0.069)\end{array}$ & $\begin{array}{c}0.133 * * \\
(0.055)\end{array}$ & $\begin{array}{c}0.296 * * * \\
(0.072)\end{array}$ & $\begin{array}{c}0.003 \\
(0.073)\end{array}$ & $\begin{array}{l}0.201^{*} \\
(0.106)\end{array}$ & $\begin{array}{c}0.088 \\
(0.078)\end{array}$ \\
\hline
\end{tabular}

Notes: Abadie-Imbens (2006) standard errors in parentheses. ${ }^{* * *} p<0.01,{ }^{*} p<0.05,{ }^{*} p<0.10$. 


\section{Discussion}

In this section we discuss two sets of results - those that refer to individual effects of national and public support and those that indicate their joint effectiveness. Still, it should be noted that the research question we investigate in this study is concerned with the policy mix, rather than individual policy effects. However, as the latter is also reported as an output of the chosen estimator, we comment on these findings similar to the situation when researchers interpret the impact of control variables on the dependent variable, although the main interest is on the impact of the variable(s) of interest.

Regarding the findings for SMEs, individual treatment effects reveal that regional and national support programmes are effective in promoting all types of cooperative behaviour, while the relative effects shed light on their joint effects as well as on differences in the effectiveness of regional versus national support. The first relevant finding is that regional support is more effective in stimulating cooperation between SMEs and government agencies than national support. In addition, we find evidence of a complementary interaction between regional and national support, relative to national support for this type of cooperation. These results taken together suggest that two categories of SMEs will benefit in terms of cooperation with the public sector: those that were only financed by regional government, and those that first received national followed by regional funding. Those SMEs that initially received regional support will not be more likely to cooperate with government agencies if they subsequently receive national support. In other words, regional support seems to play a particularly important role in stimulating cooperation with government agencies. Besides cooperation with the public support, our results do not indicate any other relative effects of regional support.

In contrast, the estimated relative effect on cooperation with HEIs hints at a more effective national support than regional. This finding is further corroborated by the significant effect of the joint support relative to regional support. Therefore, our results point out that SMEs are more likely cooperate with universities if they received support from both funding sources, rather than solely from regional government. Because firms usually cooperate with universities to share risks and costs associated with basic research, this would imply that firms would require a substantial amount of public support, which is usually provided by the central government. 
A joint provision of public support at different administrative levels does not encourage firms to increase their cooperation with competitors. The relative effects also show that neither regional nor national support is more effective in promoting cooperation with this type of partner. Therefore, with respect to policy effectiveness, it makes no difference whether firms receive regional and national support, as both individually are equally effective. However, when both types of support are received, their joint effect is not larger than individual ones. That is, we find no evidence that a multilevel governance increases the probability of cooperating with competitors.

Results for vertical cooperation (with customers and suppliers) are quite heterogenous. First, we find that regional support is equally effective as national support in increasing the probability of cooperating with customers. Second, the joint effectiveness of support is higher than either source of support individually. This means that public support can increase this type of cooperation irrespective of its administrative source. With respect to cooperation with suppliers, the joint effect is larger relative to regional support. In other words, those firms that receive regional support will increase their propensity to cooperate with suppliers if they additionally receive national support. The opposite does not hold - those SMEs that received national support are unlikely to increase their cooperation if they are also supported by regional government. ${ }^{12}$ Finally, in terms of private knowledge providers (i.e. consultants), our results indicate that the joint provision of public support is more effective than national support in isolation. In other words, those SMEs that receive national support, will be inclined to cooperate with consultants if they also receive regional support.

In summary, we find a heterogeneous evidence with respect to the joint effectiveness of regional and national support in fostering SME cooperation with various partners. The only straightforward result is for cooperation with customers in which case a multilevel governance is more effective than any individual level of support. For other cooperative partners, a joint effect is often larger than an individual effect, but the latter varies with a type of partner.

\footnotetext{
12 These results might be interpreted from the perspective of differences between national and regional support programmes. Namely, as the former is often larger in terms of the amount of funding, those firms that initially receive national support use it to finance large, risky innovation projects which would require more extensive cooperation with suppliers. Upon receiving additional support from a regional government, those additional funds might be used for financing new or existing projects that can be supported by existing network of suppliers. In other words, while national support would induce additionality effects, receiving additional (regional) support might be prone to crowding-out effects. This would explain the results that both treatments taken together are not worse than the national support alone. In the opposite case, when firms initially receive regional support followed by national funding, the possibility of crowding out is smaller, as firms cannot a priori be certain that larger funding would be available.
} 
Namely, both sources are more effective than regional support in isolation in promoting cooperation with customers, suppliers and HEIs, while the joint effect is also larger for cooperation with customers, government and consultants, relative to national support in isolation.

With respect to large firms, the estimated absolute effects show that national support in isolation increases the probability of cooperation with all partners, except with HEIs. We posit two potential explanations for the lack of policy mix in relation to cooperation of large firms with universities: either large firms cooperate with them at an optimal level before receiving public support, or they use national funding to engage in other types of cooperation and use regional funding to establish and/or maintain cooperation with universities. While we cannot test the first assumption, the second proposition finds at least a partial support in our findings. Namely, our results indicate a marginally significant policy effect of regional support on cooperation with universities. Moreover, besides this type of cooperation, regional support increases the probability of cooperation with government institutions. Looking at the summary statistics in Table 2, we can see that the highest proportion of large firms ( 35 per cent) cooperate with the government. Perhaps the reason for this high uptake is due to a positive experience that large firms have in collaborating with government institutions. Yes, without regional public support, this number would probably be lower. With respect to the policy mix, our results uniformly suggest larger joint effects on each type of collaborative partner, than individual policy effects.

However, we need to bear in mind that these are absolute effects, which means that they show policy effects when the control groups are firms that did not receive either national or regional support. To further explore the effectiveness of policy mix, we need to look at relative effects. Here we found some interesting results. First, in terms of national support versus regional support, the estimated policy effects indicate that no governance level is more effective in supporting any type of cooperation than its counterpart. Second, the policy mix is more effective than receiving regional support in isolation concerning vertical cooperation with customers and horizontal cooperation (with competitors). For other types of cooperation, our results do not support a complementary relationship between national and regional funding. These results point out to a substantial scope for policy coordination if the effectiveness of the policy mix is to be maximised in the future. This conclusion is reinforced when we compare the policy mix relative to national support, in which case, we find no evidence of joint, synergistic policy effects. In other words, once large firms receive national support (which is 
highly effective in fostering cooperative behaviour, as we can see from the absolute effects), there is no additional benefit from receiving regional support as well.

\section{Conclusions and policy implications}

Although theoretical considerations of the concept of the policy mix of innovation policy are well developed, there is very little empirical evidence that proffers evidence-based policymaking. Our study explores one dimension of the policy mix, that of a multilevel governance or the interplay between innovation policies at different administrative levels, specifically regional and national support in Spanish manufacturing firms. As the policy mix in Spain, like in most countries, is not intentionally designed, we report findings in relation to operational complementarity. In addition, the focus of the study is on the less investigated type of additionality, i.e. behavioural additionality, in particular network additionality. Given a wellknown heterogeneity with respect to firm size and innovation behaviour and performance, we investigate the effectiveness of a multilevel governance in promoting cooperative behaviour among SMEs as well as in large firms.

For SMEs, the only complementary policy effect, irrespective of the comparison funding source, is found for cooperation with customers. The other complementary effects are conditional on the source of funding that serves as the comparison group. Namely, both sources are more effective than regional support in isolation in promoting cooperation with suppliers and HEIs. Those SMEs that are solely funded by national support would benefit from a multilevel governance in case of cooperation with government agencies and consultants. These results point out few policy implications. First, given the prominent role of university-industry cooperation in a contemporary innovation policy, our findings suggest that SMEs would benefit from a joint provision of innovation support from both administrative levels, rather than solely from regional government. Second, concerning other knowledge providers (i.e. government agencies and consultants), the complementary policy mix is achieved when regional support is added to national funding. With this type of cooperation, as noted in Section 3.3, we can assume that geographical proximity plays a prominent role, hence an additional policy effect of regional support.

With regards to large firms, we find a limited evidence on complementarity between regional and national support. Namely, the policy mix seems to produce synergistic effects when large firms cooperate with other firms, specifically with customers and competitors. In contrast, the results suggest no complementary effects for cooperation with knowledge 
providers. There are at least two potential explanations for this finding: large firms could either cooperate with knowledge providers at an optimal level before receiving public funding, or the policy coordination failure is particularly pertinent in this type of cooperation. Further investigation of this finding would require a qualitative analysis, i.e. interviews and case studies with both large firms and policy makers. In any case, our findings provide a solid basis for further exploration of this lack of policy mix effects.

Overall, our empirical findings might point out at a policy coordination failure arising from the lack of coordination between isolated government departments that design and implement related policies (Magro, Navarro, and Zabala-Iturriagagoitia 2014). Consequently, increasing the effectiveness of the policy mix through policy coherence and coordination has taken a central stage among policy makers (Flanagan and Uyarra 2016). Furthermore, Flanagan and Uyarra (2016) argue that policy coordination might not produce desirable results as policy dynamics are evolving over time, encompassing changes in policy goals, rationales and instruments. Even if in the case of strategic complementarities, when policy interventions are intentionally designed to achieve synergistic effects, these theorised effects might not materialise in practice (Flanagan and Uyarra 2016).

Empirical investigation into behavioural additionality is still in its nascent years. Similar to most previous studies, available data does not allow us to assess the effectiveness of public support on other categories of firms' behaviour, such as cognitive capacity additionality, i.e. changes in managers' competencies and expertise (Busom and Fernandez-Ribas 2008; Antonioli, Marzucchi, and Montresor 2014; Cerulli, Gabriele, and Potì 2016). Second, findings from our study should be considered in the light of arguments put forward by Flanagan, Uyarra, and Laranja (2011). Namely, they emphasise the dynamic features of the processes, such that policy instruments change over time, innovation ecosystem in which they operate changes over time and the interaction within the policy mix change over time. In other words, our findings are likely to be short-run or transient (Cunningham et al. 2016b; Flanagan, Uyarra, and Laranja 2011). This implies that a continuous evaluation of the policy mix, preferable utilising longitudinal data and thus capturing the dynamic features of innovation policy, is highly desirable. Availability of panel data would also enable us to estimate the full impacts of innovation policy, which can only be evaluated covering a longer period of time (Edler et al. 2016). Finally, because of the lack of data on individual policy instruments in the CIS 2012 survey, we cannot explore the instrument mix, e.g. R\&D subsidies versus R\&D tax credits, or the supply-side policy measures versus demand-side measures. 


\section{Acknowledgments}

David Douglas wishes to thank Eurostat for providing access to the anonymised CIS microdata. He also emphasises that the results and conclusions cannot be attributed to Eurostat, the European Commission or any of the national authorities whose data have been used.

\section{References}

Abadie, A., and G. Imbens. 2006. "Large Sample Properties of Matching Estimators for Average Treatment Effects." Econometrica 74 (1): 235-267.

Afcha-Chàvez, S.M. 2011. "Behavioural additionality in the context of regional innovation policy in Spain.” Innovation: Management, Policy and Practice 13 (1): 95-110.

Afcha-Chàvez, S.M., and J. Garcia-Quevedo. 2016. "The impact of R\&D subsidies on R\&D employment composition." Industrial and Corporate Change 25 (6): 955-975.

Almus, M., and D. Czarnitzki. 2003. "The Effects of Public R\&D Subsidies on Firms' Innovation Activities: The Case of Eastern Germany." Journal of Business and Economic Statistics 21 (2): 226-236.

Antonioli, D., and A. Marzucchi. 2012. "Evaluating the additionality of innovation policy. A review focused on the behavioural dimension." World Review of Science, Technology and Sustainable Development 9 (2/3/4): 124-148.

Antonioli, D., A. Marzucchi, and S. Montresor. 2014. "Regional Innovation Policy and Innovative Behaviour: Looking for Additional Effects." European Planning Studies 22 (1): 64-83.

Arranz, N., and J.C.F. de Arroyabe. 2008. "The choice of partners in R\&D cooperation: An empirical analysis of Spanish firms." Technovation 28 (1-2): 88-100.

Aschhoff, B., and Sofka, W. (2009). "Innovation on Demand - Can Public Procurement Drive Market Success of Innovations?” Research Policy 3 (8): 1235-1247.

Belderbos, R., M. Carree, and B. Lokshin. 2004. "Cooperative R\&D and firm performance." Research Policy 33 (10): 1477-1492.

Bellucci et al. (2019). "Public R\&D subsidies: collaborative versus individual place-based programs for SMEs." Small Business Economics 52 (1): 213-240.

Borrás, S. 2009. The widening and deepening of innovation policy: What conditions provide for effective governance? CIRLE Working Paper 2009/02.

Buisseret, T.J., H.M. Cameron, and L. Georghiou. 1995. "What Difference Does It Make Additionality in the Public Support of R-and-D in Large Firms." International Journal of Technology Management 10 (4-6): 587-600.

Busso, M., J. DiNardo, and J. McCrary. 2014. "New Evidence on the Finite Sample Properties of Propensity Score Reweighting and Matching Estimators." Review of Economics and Statistics 96: 885-897.

Busom, I., and A. Fernandez-Ribas. 2008. "The Impact of Firm Participation in R\&D Programmes on R\&D Partnerships." Research Policy 37(2): 240-257.

Cantabene, C., and Grassi, I. 2019. "Public and private incentives to R\&D cooperation in Italy." Economics of Innovation and New Technology 28 (3): 217-242.

Cassiman, B., and R. Veugelers. 2002. "R\&D Cooperation and Spillovers: Some Empirical Evidence from Belgium." American Economic Review 92 (4): 1169-1184.

Cattaneo, M.D. 2010. "Efficient semiparametric estimation of multi-valued treatment effects under ignorability." Journal of Econometrics 155: 138-154. 
Cattaneo, M.D., D.M. Drukker, and A.D. Holland. 2013. "Estimation of Multivalued Treatment Effects under Conditional Independence.” Stata Journal 13: 407-450.

Cerulli, G. 2010. "Modelling and measuring the effect of public subsidies on business R\&D: a critical review of the econometric literature." Economic Record 86 (274): 421-449.

Cerulli, G., R. Gabriele, and B. Potì. 2016. "The role of firm R\&D effort and collaboration as mediating drivers of innovation policy effectiveness." Industry and Innovation 23 (5): 426-447.

Chun, H., and S.-B. Mun. 2012. "Determinants of R\&D Cooperation in Small and MediumSized Enterprises." Small Business Economics 39 (2): 419-436.

Cohen, W.M., and D.A. Levinthal. 1990. "Absorptive Capacity: A New Perspective on Learning and Innovation.” Administrative Science Quarterly 35 (1): 128-152.

Cunningham, P., and A. Gök. 2012. "The impact of innovation policy schemes for collaboration”. In Handbook of Innovation Policy Impact. (Eu-SPRI Forum on Science, Technology and Innovation Policy series), edited by Edler, J., P. Cunningham, A. Gök, and P. Shapira, 239-278, Cheltenham: Edward Elgar.

Cunningham, P., A. Gok, and P. Laredo. 2016a. "The Impact of Direct Support to R\&D and Innovation in Firms." In Handbook of Innovation Policy Impact. (Eu-SPRI Forum on Science, Technology and Innovation Policy series), edited by Edler, J., P. Cunningham, A. Gök, and P. Shapira, 54-92, Cheltenham: Edward Elgar.

Cunningham, P., J. Edler, K. Flanagan, and P. Laredo. 2016b. "The innovation policy mix." In Handbook of Innovation Policy Impact. (Eu-SPRI Forum on Science, Technology and Innovation Policy series), edited by Edler, J., P. Cunningham, A. Gök, and P. Shapira, 505-542, Cheltenham: Edward Elgar.

Curran, J. 2000. "What is Small Business Policy in the UK for? Evaluation and Assessing Small Business Policies." International Small Business Journal 18 (3): 36-50.

Czarnitzki, D., B. Ebersberger, and A. Fier. 2007. "The Relationship Between R\&D Collaboration, Subsidies and R\&D Performance: Empirical Evidence from Finland and Germany." Journal of Applied Econometrics 22 (7): 1347-1366.

Czarnitzki, D., and C. Lopes-Bento. (2014). "Innovation Subsidies: Does the Funding Source Matter for Innovation Intensity and Performance? Empirical Evidence from Germany." Industry and Innovation 21 (5): 380-409.

Del Río P. 2014. "On evaluating success in complex policy mixes: the case of renewable energy support schemes." Policy Sciences 47 (3): 1-21.

Dhont-Petrault, E., and E. Pfister. 2011. "R\&D Cooperation Versus R\&D Subcontracting: Empirical Evidence from French Survey Data." Economics of Innovation and New Technology 20 (4): 309-341.

Dimos, C., and G. Pugh. 2016. "The Effectiveness of R\&D Subsidies: A Meta-Regression Analysis of the Evaluation Literature." Research Policy 45 (4): 797-815.

Doloreux, D., and R. Shearmur. 2012. "Collaboration, information and the geography of innovation in knowledge intensive business services." Journal of Economic Geography 12 (1): 79-105.

Edler, J., P. Shapira, P. Cunningham, and A. Gok. 2016. "Conclusions: Evidence on the Effectiveness of Innovation Policy Intervention." In Handbook of Innovation Policy Impact. (Eu-SPRI Forum on Science, Technology and Innovation Policy series), edited by Edler, J., P. Cunningham, A. Gök, and P. Shapira, 543-564, Cheltenham: Edward Elgar.

Edquist, C. 1999. "Systems of Innovation: Theory and policy for the demand side." Technology in Society 21 (1): 63-79.

Emsley, R., M. Lunt, A. Pickles, and G. Dunn. 2008. "Implementing Double-Robust Estimators of Causal Effects.” Stata Journal 8 (3): 334-353. 
Faiña, A., and J. Lopez-Rodriguez. 2010. Expert evaluation network delivering policy analysis on the performance of Cohesion Policy 2007-2013. Task 1: Policy paper on innovation Spain. A report to the European Commission Directorate-General Regional Policy.

Falk, R. 2007. "Measuring the effects of public support schemes on firms' innovation activities: Survey evidence from Austria." Research Policy 36 (5): 665-679.

Fernández-Ribas, A. (2009). "Public support to private innovation in multi-level governance systems: an empirical investigation." Science and Public Policy 36 (6): 457-467.

Fernández-Ribas, A., and P. Shapira. 2009. "The role of national and regional-level innovation programs in stimulating international cooperation in innovation." International Journal of Technology Management 48 (4): 473-498.

Flanagan, K., E. Uyarra, and M. Laranja. 2011. "Reconceptualising the 'policy mix' for innovation." Research Policy 40 (5): 702-713.

Flanagan, K., and E. Uyarra. 2016. "Four dangers in innovation policy studies - and how to avoid them." Industry and Innovation 23 (2): 177-188.

Franco, C. and M. Gussoni (2014). "The role of firm and national level factors in fostering R\&D cooperation: a cross country comparison." Journal of Technology Transfer 39: 945-976.

Georghiou, L., and B. Clarysse. 2006. "Behavioural Additionality of R\&D Grants: Introduction and Synthesis." In Government $R \& D$ Funding and Company Behaviour: Measuring Behavioural Additionality, edited by OECD, 9-38. Paris: OECD Publishing.

Ghazinoory, S., M. Amiri, S. Ghazinoori, and P. Alizadeh. 2019. "Designing innovation policy mix: a multi-objective decision-making approach." Economics of Innovation and New Technology 28 (4): 365-385.

Grimpe, C., and W. Sofka. 2008. "Search Patterns and Absorptive Capacity: Low- and HighTechnology Sectors in European Countries.” Research Policy 38 (3): 495-506.

Gök, A., and J. Edler. 2012. "The use of behavioural additionality evaluation in innovation policy making." Research Evaluation 21 (4): 306-318.

Guerzoni, M., and E. Raiteri. 2015. "Demand-side vs. Supply-side Technology Policies: Hidden Treatment and New Empirical Evidence on the Policy Mix." Research Policy 44: 726-47.

Hall, B.H., and A. Maffioli. 2008. "Evaluating the impact of technology development funds in emerging economies: evidence from Latin America." European Journal of Development Research 20 (2): 172-198.

Heckman, J. J., and E. J. Vytilacil. 2007. "Econometric Evaluation of Social Programs, Part I: Causal Models, Structural Models and Econometric Policy Evaluation." In Handbook of Econometrics, vol. 6, edited by Heckman, J.J., and E.E., Leamer, 4779-4873. Amsterdam: Elsevier.

Hirano, K., G.W. Imbens, and G. Ridder. 2003. "Efficient Estimation of Average Treatment Effects Using the Estimated Propensity Score.” Econometrica 71: 1161-1189.

Howlett, M., Y.P. How, and del Rio, P. (2015). "The parameters of policy portfolios: verticality and horizontality in design spaces and their consequences for policy mix formulation." Environment and Planning C: Government and Policy 33: 1233 - 1245.

Imbens, G.W. 2004. "Nonparametric Estimation of Average Treatment Effects under Exogeneity: A Review." Review of Economics and Statistics 86 (1): 4-29.

Imbens, G.W., and J.M. Wooldridge. 2009. "Recent Developments in the Econometrics of Program Evaluation." Journal of Economic Literature 47 (1): 5-86.

Innovation Union Scoreboard. 2013. European Commission. 
https://ec.europa.eu/growth/tools-databases/eiprawmaterials/en/system/files/ged/69\%20Innovation\%20Union\%20Scoreboard\%2020 13 en.pdf

Lanahan, L., and M.P. Feldman. 2015. "Multilevel innovation policy mix: A closer look at state policies that augment the federal SBIR program." Research Policy 44: 1387-1402.

Lechner, M. 2001. "Identification and estimation of causal effects of multiple treatments under the conditional independence assumption." In Econometric Evaluation of Labour Market Policies, edited by Lechner, M., and F. Pfeiffer, 43-58. Heidelberg: Physica.

Lechner, M. 2002a. "Program heterogeneity and propensity score matching: An application to the evaluation of active labor market policies." Review of Economics and Statistics 84 (2): 205-220.

Lechner, M. 2002b. "Some practical issues in the evaluation of heterogeneous labour market programmes by matching methods." Journal of the Royal Statistical Society. Series A: Statistics in Society 165 (1): 59-82.

Linden, A., S.D. Uysal, A. Ryan, and J.L. Adams. 2016. "Estimating causal effects for multivalued treatments: a comparison of approaches." Statistics in Medicine 35 (4): 534-552.

Magro, E., M. Navarro, and J.M. Zabala-Iturriagagoitia. 2014. "Coordination-Mix: The Hidden Face of STI Policy." Review of Policy Research 31 (5): 367-389.

Magro, E., and J.R. Wilson. 2013. "Complex innovation policy systems: Towards an evaluation mix." Research Policy 42 (9): 1647-1656.

Magro, E., and J.R. Wilson. 2019. "Policy-mix evaluation: Governance challenges from new place-based innovation policies." Research Policy 48 (10): 103612.

Marchese, M., and J. Potter. 2010. "Entrepreneurship, SMEs and Local Development in Andalusia, Spain.” LEED Working Paper Series, LEED programme, OECD.

Martin, B.R. 2016. "R\&D policy instruments- a critical review of what we do and don't know." Industry and Innovation 23 (2), 157-176.

Marzucchi, A., and S. Montresor. 2015. "The multi-dimensional additionality of innovation policies: A multi-level application in Italy and Spain." In The Economics of Knowledge, Innovation and Systemic Technology Policy, edited by Crespi, F., and F. Quatraro, 239270. New York: Routledge.

Marzucchi, A., D. Antonioli, and S. Montresor. 2015. "Industry-research co-operation within and across regional boundaries. What does innovation policy add?" Papers in Regional Science 94 (3): 499-524.

Miotti, L., and F. Sachwald. 2003. "Co-operative R\&D: Why and with whom? An integrated framework of analysis." Research Policy 32 (8): 1481-1499.

Mohnen, P., and C. Hoareau. 2003. "What type of enterprise forges close links with universities and government labs? Evidence from CIS 2." Managerial and Decision Economics 24 (2-3): 133-145.

Nelson, R.R., and G.S. Winter. 1982. An Evolutionary Theory of Economic Change. Cambridge: Belknap Press of Harvard University Press.

OECD. 2006. Government R\&D Funding and Company Behaviour: Measuring Behavioural Additionality. Paris: OECD Publishing.

OECD. 2010. “The Innovation Policy Mix." In OECD Science, Technology and Industry Outlook 2010, 251-279, Paris: OECD Publishing.

OECD. 2011. Regions and Innovation Policy. Paris: OECD Publishing.

Radas, S., I.-D. Anic, A. Tafro, and V. Wagner. 2015. "The effects of public support schemes on small and medium enterprises." Technovation 38: 15-30. 
Radicic, D. 2019. "Effectiveness of public procurement of innovation versus supply-side innovation measures in manufacturing and services." Science and Public Policy 46 (5): 732-746.

Radicic, D., and M. Balavac. 2019. "In-house R\&D, external R\&D and cooperation breadth in Spanish manufacturing firms: is there a synergistic effect on innovation outputs?" Economics of Innovation and New Technology 28 (6): 590-615.

Radicic, D., D. Douglas, G. Pugh, and I. Jackson. 2019. "Cooperation for innovation and its impact on technological and non-technological innovations: empirical evidence for European SMEs in traditional manufacturing industries." International Journal of Innovation Management 23 (5): 1950046.

Radicic, D., and J. Pinto. 2019. "Collaboration with External Organizations and Technological Innovations: Evidence from Spanish Manufacturing Firms." Sustainability 11 (9): 2479.

Radicic, D., and G. Pugh. 2017. "Performance effects of open innovation in European small and medium-sized enterprises." Journal of Small Business Management 55 (S1): 76114.

Radicic, D., G. Pugh, and D. Douglas. 2020. "Promoting cooperation in innovation ecosystems: evidence from European traditional manufacturing SMEs.” Small Business Economics 54 (1): 257-283.

Radicic, D., G. Pugh, H. Hollanders, R. Wintjes, and J. Fairburn. 2016. "The impact of innovation support programmes on SME innovation in traditional manufacturing industries: an evaluation for seven EU regions." Environment and Planning C: Government and Policy 34 (8): 1425-1452.

Rogge, K.S., and K. Reichardt. 2016. "Policy mixes for sustainability transitions: An extended concept and framework for analysis." Research Policy 45: 1620-1635.

Schot, J., and Steinmueller, W.E. (2018). "Three frames for innovation policy: R\&D, systems of innovation and transformative change." Research Policy 47: 1554-1567.

Spithoven, A., P. Teirlinck, and D. Frantzen. 2012. Managing Open Innovation: Connecting the Firm to External Knowledge. London: Edward Elgar Publishing.

SQW Consulting. 2009. "Synthesis of Evaluation Evidence: Final Report for the Department for Business, Enterprise and Regulatory Reform.” London: BIS.

Teirlinck, P., and A. Spithoven. 2012. "Fostering industry-science cooperation through public funding: differences between universities and public research centres." Journal of Technology Transfer 37 (5): 676-695.

Uyarra, E. 2010. "What is evolutionary about 'regional systems of innovation'? Implications for regional policy.” Journal of Evolutionary Economics 20: 115-137.

Uyarra, E., and Flanagan, K. 2010. "Understanding the Innovation Impacts of Public Procurement.” European Planning Studies 18 (1): 123-143.

Wanzenböck, I., T. Scherngell, and M.M. Fischer. 2013. "How do firm characteristics affect behavioural additionality of public R\&D subsidies? Evidence for the Austrian transport sector." Technovation 33 (2-3): 66-77.

Williamson, O.E. 1985. The Economic Institutions of Capitalism. New York: The Free Press. Wooldridge, J. M. 2010. Econometric Analysis of Cross Section and Panel Data. 2nd edition. Cambridge, Massachusetts: MIT Press. 


\section{Appendix}

Figure A1. Checking the overlap assumption for SMEs

Treatment $=0$

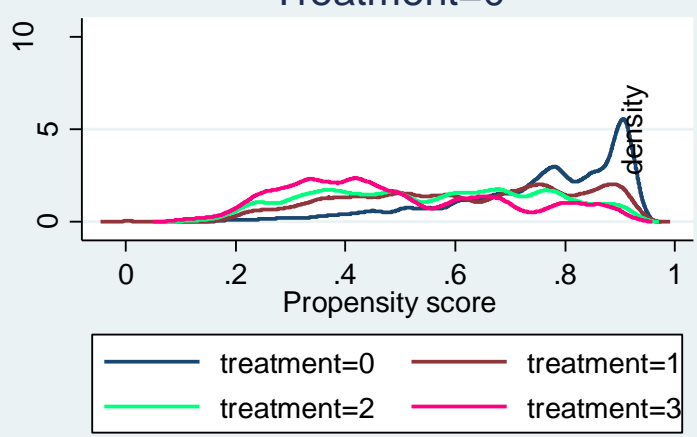

Treatment $=2$

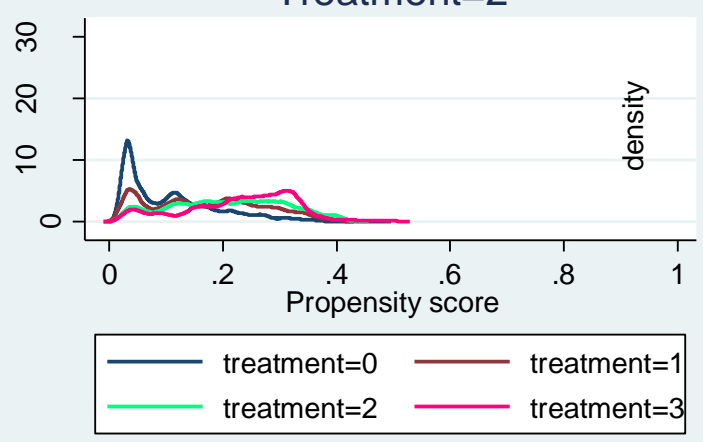

Treatment $=1$

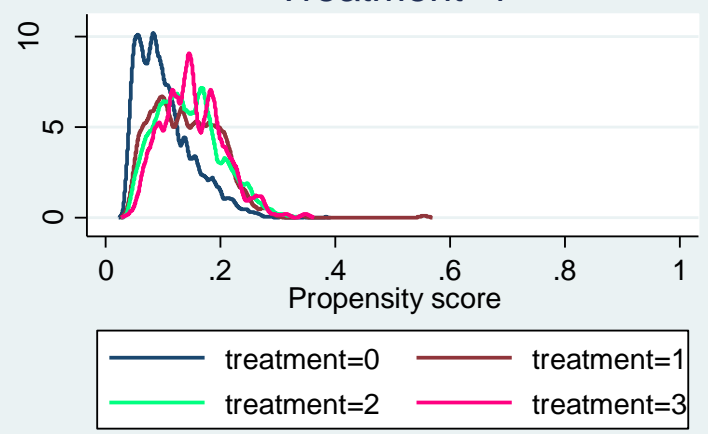

Treatment $=3$

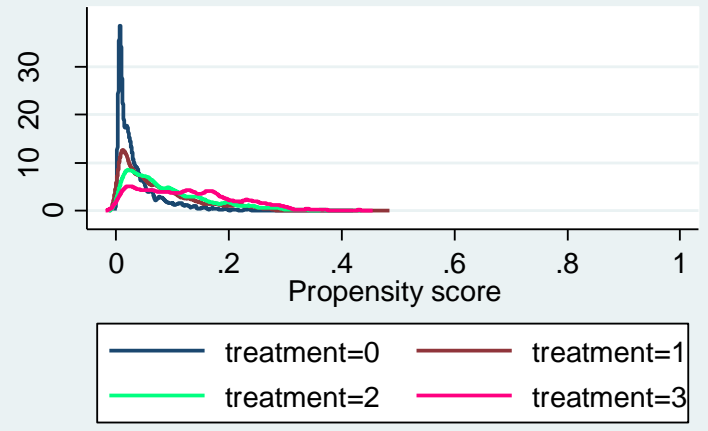


Figure A2. Checking the overlap assumption for large firms
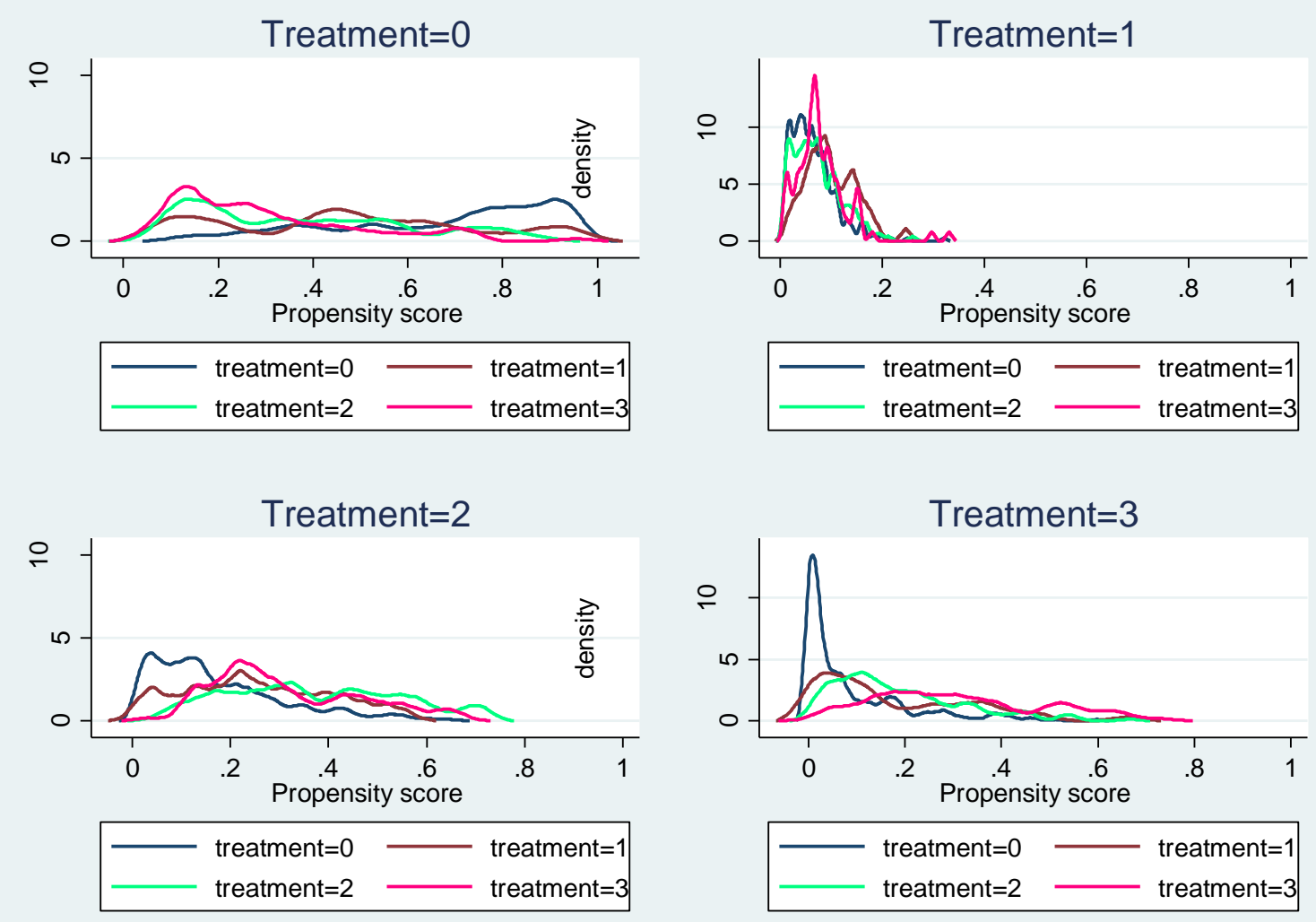
Table A1. Estimation functions (the outcome and the treatment models) for the outcome variable Cooperation with customers with treatment level 0 as the base (reference) category $(\mathrm{N}=\mathbf{5 , 0 4 5})$

\begin{tabular}{|c|c|c|c|c|c|c|c|}
\hline \multirow[b]{2}{*}{$\begin{array}{c}\text { Independent } \\
\text { variables }\end{array}$} & \multicolumn{4}{|c|}{ Outcome model } & \multicolumn{3}{|c|}{ Treatment model } \\
\hline & $\begin{array}{l}\text { Potential } \\
\text {-outcome } \\
\text { model for } \\
\text { treatment } \\
\quad=0\end{array}$ & $\begin{array}{l}\text { Potential } \\
\text {-outcome } \\
\text { model for } \\
\text { treatment } \\
=1\end{array}$ & $\begin{array}{l}\text { Potential } \\
\text {-outcome } \\
\text { model for } \\
\text { treatment } \\
=2\end{array}$ & $\begin{array}{l}\text { Potential } \\
\text {-outcome } \\
\text { model for } \\
\text { treatment } \\
=3\end{array}$ & $\begin{array}{c}\text { Treatment } \\
=1\end{array}$ & $\begin{array}{c}\text { Treatment } \\
=2\end{array}$ & $\begin{array}{c}\text { Treatment } \\
=3\end{array}$ \\
\hline Group & $0.574 * * *$ & -0.220 & 0.062 & 0.249 & -0.166 & 0.129 & $0.271^{*}$ \\
\hline & $(0.182)$ & $(0.285)$ & $(0.230)$ & $(0.374)$ & $(0.108)$ & $(0.100)$ & $(0.145)$ \\
\hline Export & $0.599 *$ & 0.130 & -0.401 & 0.855 & 0.159 & $0.465 * * *$ & $0.575^{* *}$ \\
\hline & $(0.312)$ & $(0.426)$ & (0.377) & (0.809) & $(0.130)$ & $(0.142)$ & $(0.236)$ \\
\hline Turnover & -0.100 & -0.137 & 0.091 & 0.083 & $0.043^{*}$ & 0.017 & 0.040 \\
\hline Growth & $(0.075)$ & $(0.190)$ & $(0.095)$ & $(0.066)$ & $(0.026)$ & $(0.026)$ & $(0.030)$ \\
\hline Internal_R\&D & $\begin{array}{c}0.668 * * * \\
(0.207)\end{array}$ & $\begin{array}{c}0.654 \\
(0.411)\end{array}$ & $\begin{array}{c}0.388 \\
(0.453)\end{array}$ & $\begin{array}{c}2.675 * * * \\
(0.796)\end{array}$ & $\begin{array}{c}0.571 * * * \\
(0.110)\end{array}$ & $\begin{array}{c}1.415^{* * * *} \\
(0.132)\end{array}$ & $\begin{array}{c}1.192 * * * \\
(0.205)\end{array}$ \\
\hline External_R\&D & $\begin{array}{l}0.325^{*} \\
(0.171)\end{array}$ & $\begin{array}{c}0.301 \\
(0.272)\end{array}$ & $\begin{array}{l}0.527 * * \\
(0.248)\end{array}$ & $\begin{array}{l}-0.614^{*} \\
(0.345)\end{array}$ & $\begin{array}{c}0.779 * * * \\
(0.102)\end{array}$ & $\begin{array}{c}0.682 * * * \\
(0.096)\end{array}$ & $\begin{array}{c}1.098 * * * \\
(0.144)\end{array}$ \\
\hline $\begin{array}{l}\text { Acquisition_- } \\
\text { machinery }\end{array}$ & $\begin{array}{c}0.123 \\
(0.221)\end{array}$ & $\begin{array}{l}-0.341 \\
(0.354)\end{array}$ & $\begin{array}{l}-0.229 \\
(0.295)\end{array}$ & $\begin{array}{c}0.695 \\
(0.479)\end{array}$ & $\begin{array}{c}0.458 * * * \\
(0.119)\end{array}$ & $\begin{array}{c}0.514 * * * \\
(0.116)\end{array}$ & $\begin{array}{c}0.392 * * \\
(0.168)\end{array}$ \\
\hline Acquisition_ & -1.013 & 0.453 & 0.561 & $-2.505 * * *$ & 0.260 & 0.277 & 0.159 \\
\hline knowledge & $(0.826)$ & $(0.680)$ & $(0.561)$ & $(0.914)$ & $(0.344)$ & $(0.318)$ & $(0.420)$ \\
\hline Training & $\begin{array}{c}0.418 * * \\
(0.211)\end{array}$ & $\begin{array}{c}0.113 \\
(0.322)\end{array}$ & $\begin{array}{l}0.500^{*} \\
(0.281)\end{array}$ & $\begin{array}{c}0.349 \\
(0.375)\end{array}$ & $\begin{array}{l}-0.255^{*} \\
(0.137)\end{array}$ & $\begin{array}{l}-0.139 \\
(0.126)\end{array}$ & $\begin{array}{c}0.348 * * \\
(0.165)\end{array}$ \\
\hline $\begin{array}{l}\text { Market_- } \\
\text { introduction }\end{array}$ & $\begin{array}{c}0.227 \\
(0.187)\end{array}$ & $\begin{array}{c}0.166 \\
(0.296)\end{array}$ & $\begin{array}{c}0.359 \\
(0.266)\end{array}$ & $\begin{array}{c}-0.481 \\
(0.378)\end{array}$ & $\begin{array}{l}-0.143 \\
(0.117)\end{array}$ & & $\begin{array}{l}-0.011 \\
(0.151)\end{array}$ \\
\hline Other_ & $0.478^{*}$ & $1.242 * * *$ & -0.011 & $1.012 *$ & 0.245 & 0.140 & 0.147 \\
\hline expenditure & $(0.270)$ & $(0.346)$ & $(0.335)$ & $(0.597)$ & $(0.172)$ & $(0.16$ & $(0.2$ \\
\hline Small_firms & $\begin{array}{c}0.172 \\
(0.181)\end{array}$ & $\begin{array}{c}0.341 \\
(0.265)\end{array}$ & $\begin{array}{l}-0.178 \\
(0.236)\end{array}$ & $\begin{array}{c}0.234 \\
(0.364)\end{array}$ & $\begin{array}{c}0.107 \\
(0.105)\end{array}$ & $\begin{array}{l}-0.044 \\
(0.096)\end{array}$ & $\begin{array}{l}-0.097 \\
(0.144)\end{array}$ \\
\hline Info_internal & $\begin{array}{c}0.732 * * \\
(0.362)\end{array}$ & $\begin{array}{c}0.444 \\
(0.551)\end{array}$ & $\begin{array}{c}0.165 \\
(0.518)\end{array}$ & $\begin{array}{c}0.705 \\
(0.847)\end{array}$ & $\begin{array}{c}0.136 \\
(0.165)\end{array}$ & $\begin{array}{l}-0.061 \\
(0.169)\end{array}$ & $\begin{array}{l}-0.055 \\
(0.275)\end{array}$ \\
\hline Info_market & $\begin{array}{c}1.074 * * * \\
(0.401)\end{array}$ & $\begin{array}{c}1.707 * * * \\
(0.578)\end{array}$ & $\begin{array}{c}0.852 \\
(0.636)\end{array}$ & $\begin{array}{c}0.812 \\
(1.081)\end{array}$ & $\begin{array}{c}0.627 * * * \\
(0.237)\end{array}$ & $\begin{array}{c}0.242 \\
(0.220)\end{array}$ & $\begin{array}{l}0.604^{*} \\
(0.350)\end{array}$ \\
\hline $\begin{array}{l}\text { Info- } \\
\text { institutional }\end{array}$ & $\begin{array}{c}0.880 * * * \\
(0.298)\end{array}$ & $\begin{array}{c}1.331 * * * \\
(0.504)\end{array}$ & $\begin{array}{c}0.783 * * \\
(0.393)\end{array}$ & $\begin{array}{c}1.717 * * * \\
(0.597)\end{array}$ & $\begin{array}{c}1.123 * * * \\
(0.180)\end{array}$ & $\begin{array}{c}1.740 * * * \\
(0.171)\end{array}$ & $\begin{array}{c}1.979 * * * \\
(0.237)\end{array}$ \\
\hline Info_others & $\begin{array}{c}0.256 \\
(0.376)\end{array}$ & $\begin{array}{c}0.421 \\
(0.593)\end{array}$ & $\begin{array}{l}1.138^{* * *} \\
(0.490)\end{array}$ & $\begin{array}{l}-0.463 \\
(0.927)\end{array}$ & $\begin{array}{l}-0.332 \\
(0.215)\end{array}$ & $\begin{array}{c}-0.618 * * * \\
(0.219)\end{array}$ & $\begin{array}{l}-0.047 \\
(0.312)\end{array}$ \\
\hline $\begin{array}{l}\text { Medium high } \\
\text { tech }\end{array}$ & $\begin{array}{c}0.395 \\
(0.248)\end{array}$ & $\begin{array}{c}0.765^{* *} \\
(0.350)\end{array}$ & $\begin{array}{c}0.249 \\
(0.370)\end{array}$ & $\begin{array}{l}-0.095 \\
(0.486)\end{array}$ & $\begin{array}{l}0.130 \\
(0.123)\end{array}$ & $\begin{array}{l}-0.026 \\
(0.126)\end{array}$ & $\begin{array}{c}0.369 * * \\
(0.187)\end{array}$ \\
\hline $\begin{array}{l}\text { Medium low } \\
\text { tech }\end{array}$ & $\begin{array}{c}0.165 \\
(0.220)\end{array}$ & $\begin{array}{l}0.609^{*} \\
(0.341)\end{array}$ & $\begin{array}{c}0.422 \\
(0.287)\end{array}$ & $\begin{array}{c}0.231 \\
(0.528)\end{array}$ & $\begin{array}{l}-0.057 \\
(0.111)\end{array}$ & $\begin{array}{l}-0.062 \\
(0.109)\end{array}$ & $\begin{array}{l}-0.010 \\
(0.177)\end{array}$ \\
\hline High tech & $\begin{array}{c}0.189 \\
(0.382)\end{array}$ & $\begin{array}{c}0.504 \\
(0.606)\end{array}$ & $\begin{array}{c}0.591 \\
(0.390)\end{array}$ & $\begin{array}{c}0.612 \\
(0.691)\end{array}$ & $\begin{array}{l}-0.290 \\
(0.213)\end{array}$ & $\begin{array}{c}0.272 \\
(0.167)\end{array}$ & $\begin{array}{c}0.716 * * * \\
(0.229)\end{array}$ \\
\hline Constant & $\begin{array}{c}-5.723 * * * \\
(0.523)\end{array}$ & $\begin{array}{c}-5.366^{* * *} \\
(0.740)\end{array}$ & $\begin{array}{c}-3.608 * * * \\
(0.771)\end{array}$ & $\begin{array}{c}-6.059 * * * \\
(1.508)\end{array}$ & $\begin{array}{c}-3.132 * * * \\
(0.197)\end{array}$ & $\begin{array}{c}-3.702 * * * \\
(0.208)\end{array}$ & $\begin{array}{c}-5.594 * * * \\
(0.378)\end{array}$ \\
\hline
\end{tabular}

Notes: Robust standard errors in parentheses; $* * * p<0.01, * * p<0.05, * p<0.10$. 